\title{
Pela lei e contra a lei - lutas e organização dos trabalhadores da construção civil de Salvador (1919-1922)
}

\section{By the law and against the law - struggles and organization of construction workers in Salvador (1919-1922)}

\section{Luciano de Moura Guimarães *}

Resumo: Em junho de 1919, os trabalhadores da construção civil de Salvador, reunidos no Sindicato dos Pedreiros, Carpinteiros e Demais Classes (SPCDC), foram os principais responsáveis pela eclosão, consecução e êxito da greve geral que virtualmente paralisou as atividades produtivas da cidade. A partir de então, essa associação incentivou a fundação de diversos sindicatos de resistência e tornou-se vetor de novas greves. Também articulou o Primeiro Congresso de Trabalhadores Baianos (julho de 1919) e colaborou decisivamente na criação da Federação dos Trabalhadores Baianos (FTB) em fevereiro de 1920. Ademais, de seu interior saíram importantes quadros que atuaram na organização do Partido Socialista Baiano (agosto de 1920). Sua atividade contou, ainda, com a publicação de dois jornais operários e com a fundação de uma escola proletária. Considerando a pluralidade das experiências históricas dos mundos do trabalho no Brasil e focalizando as múltiplas práticas e iniciativas sustentadas pelos militantes do SPCDC, procuramos identificar as especificidades e as regularidades presentes no caso baiano em relação a outras experiências. A circulação de ideias e ativistas - socialistas e anarquistas - constitui-se, assim, num importante fator para clarificar a compreensão das manifestações proletárias do período em Salvador. Pois, nutrindo-se de estímulos provenientes de outras regiões do país e do mundo, tais como campanhas, greves e reivindicações, mas baseados também em suas próprias experiências de exploração e sobrevivência, os operários baianos conseguiram auferir vantagens materiais, organizativas e políticas. Para tanto, urdiram

\footnotetext{
* Mestre em História Social pela Universidade Federal da Bahia (UFBA). Doutorando em História Social da Cultura na Pontifícia Universidade Católica do Rio de Janeiro (PUC-Rio). ORCID: https://orcid.org/0000-00032625-6701. E-mail: luccianomg@gmail.com.
} 
laços de solidariedade e identidade classista que possibilitaram afirmarem-se como um ator social e político habilitado na sociedade soteropolitana.

Palavras-chave: sindicalismo; movimento operário; Salvador-Bahia.

Abstract: In June 1919, the construction workers of Salvador, members of the Union of Bricklayers, Carpenters and Other Classes (SPCDC), were fundamentally responsible for the early engage, accomplishment and success of the general strike that nearly paralyzed the productive activities of the entire city. Since then, this labor union encouraged the founding of several others organizations of unionized workers resistence, which originated widespread strikes. Those unionized workers also promoted the First Congress of Workers of Bahia (July 1919) and collaborated decisively in the creation of the Federation of Bahia's Workers, in February 1920. In addition, important figures emerged from its core who acted in the organization of the Socialist Party of Bahia (August 1920). Among the activities the bricklayers's union used to promoted, were also included publishing two labor newspapers and founding a proletarian school. Considering the diversity of Brazil's worlds of labour historical experiences and focusing on the multiple practices and initiatives held by SPCDC's militants, we sought to identify the specific features and regularities present in the case of Bahia in relation to other experiences. The circulation of ideas and activists - socialists and anarchists - constitutes, therefore, an important factor to clarify the understanding of the proletarian manifestations of the period in Salvador. Thus, incited by encouragement from other parts of the country and the world, such as campaigns, strikes and demands, but also based on their own experiences of exploration and survival, Bahia's workers were able to earn material, organizational and political advantages. For that, they formed alliances of solidarity and class identity that enabled them to establish themselves as social and political agents in Salvador's society.

Keywords: unionism; labour movement; City of Salvador-Bahia

$N^{2}$ O DIA 2 DE JUNHO DE 1919, por volta das 13 horas, operários da construção civil que trabalhavam nas obras da Biblioteca Pública do Estado da Bahia, em Salvador, resolveram paralisar o serviço. Aproveitando o intervalo destinado ao almoço, quando puderam conversar, articularam a ação. Suas reivindicações consistiam em aumento salarial de $20 \%$ e no estabelecimento da jornada de oito horas de trabalho. Concentrando-se na praça Rio Branco, bem no coração do centro histórico e administrativo de Salvador, receberam adesões de trabalhadores das obras do Tesouro do Estado, do Palácio do Governo e de outras obras particulares. ${ }^{1}$ Em seguida, de acordo com o jornal $A$ Tarde, fizeram uma passeata, berrando

1 A Biblioteca Pública do Estado da Bahia localizava-se na antiga praça Rio Branco, atual praça Thomé de Souza, onde também se situavam o Palácio Rio Branco, sede do governo estadual e a Câmara Municipal de Salvador. A centralidade do local é reforçada pela presença do Elevador Lacerda, uma das principais ligações 
"vivas" aos trabalhadores e carregando cartazes com dizeres como "oito horas de trabalho já são bastante ao operariado baiano". Depois de seguirem até a Ladeira da Barra, retornaram ao centro da cidade, conservando-se "na maior ordem". ${ }^{2}$ No caminho lograram obter novas adesões, dos trabalhadores de padarias e dos funcionários da Companhia Linha Circular, empresa operadora de bondes. Durante o trajeto pediram apoio aos jornais da grande imprensa que se localizavam nas vias percorridas e, no final da tarde, totalizavam mais de mil aderentes.

O préstito continuou até a sede do Sindicato dos Pedreiros, Carpinteiros e Demais Classes (SPCDC), que havia sido fundado em março do mesmo ano, e era sito na rua do Maciel de Baixo, 24, atual Pelourinho, onde, naquela mesma noite, realizou-se um encontro. Deste participaram os membros da diretoria do SPCDC, da União Defensora e Beneficente dos Pintores da Bahia e da Sociedade União dos Operários em Padaria, além de lideranças não nomeadas pelos jornais. Tomaram a palavra diversos sindicalistas, além de um jornalista do Diário da Bahia, periódico vinculado à oposição estadual e aos grandes industriais e comerciantes. $^{3}$

Nos dias seguintes, a parede disseminou-se com a adesão de muitos trabalhadores dos transportes urbanos, dos ferroviários das companhias Central da Bahia, Bahia-São Francisco e Chemins de Fer, dos operários das fábricas de tecidos, de cigarros, de calçados, dos que trabalhavam em camisarias, nas alfaiatarias, nas oficinas de costura, dos operários das obras do porto, dos empregados das Docas Wilson Sons, dos funcionários das usinas da Graça e da Preguiça, responsáveis pela geração de energia elétrica da cidade, dos operários das linhas de bondes, dos padeiros, dos trabalhadores em açougues, hotéis, bares e restaurantes e também dos coveiros do Cemitério Quinta dos Lázaros. ${ }^{4}$ Logo a cidade ficou privada do fornecimento de luz, energia, telefone e transportes, praticamente paralisando-se a capital.

entre as cidades Alta e Baixa. Hoje em dia, a sede da Prefeitura de Salvador ergue-se no mesmo local em que erigiram o prédio da Biblioteca Pública. O edifício do Tesouro do Estado ficava a alguns metros dali, descendo a rua Chile, em direção à avenida Sete de Setembro.

2 A Tarde, Salvador, 3 jun. 1919.

3 Os jornais da época estavam, em sua maioria, ligados à política partidária. O surgimento de muitos deles, assim como seu desaparecimento, vinculava-se intimamente à existência ou extinção dos grupamentos político-partidários. Alguns traziam em seus cabeçalhos a filiação política a qual pertenciam, ou os interesses de classe que defendiam. Assim, por exemplo, O Imparcial, designava-se "órgão das classes conservadoras", enquanto O Democrata assumia ser o porta-voz do Partido Republicano Democrata (PRD), agremiação dirigida por J. J. Seabra e pelo governador Antônio Moniz.

4 TAVARES, Luiz Henrique Dias. História da Bahia. $11^{\mathrm{a}}$ ed. rev. e ampl. Salvador: EDUFBA; São Paulo: Editora da UNESP, 2008. p. 338; e CASTELLUCCI, Aldrin. Industriais e operários numa conjuntura de crise (19141921). Salvador: Fieb, 2004. p. 189-208. 


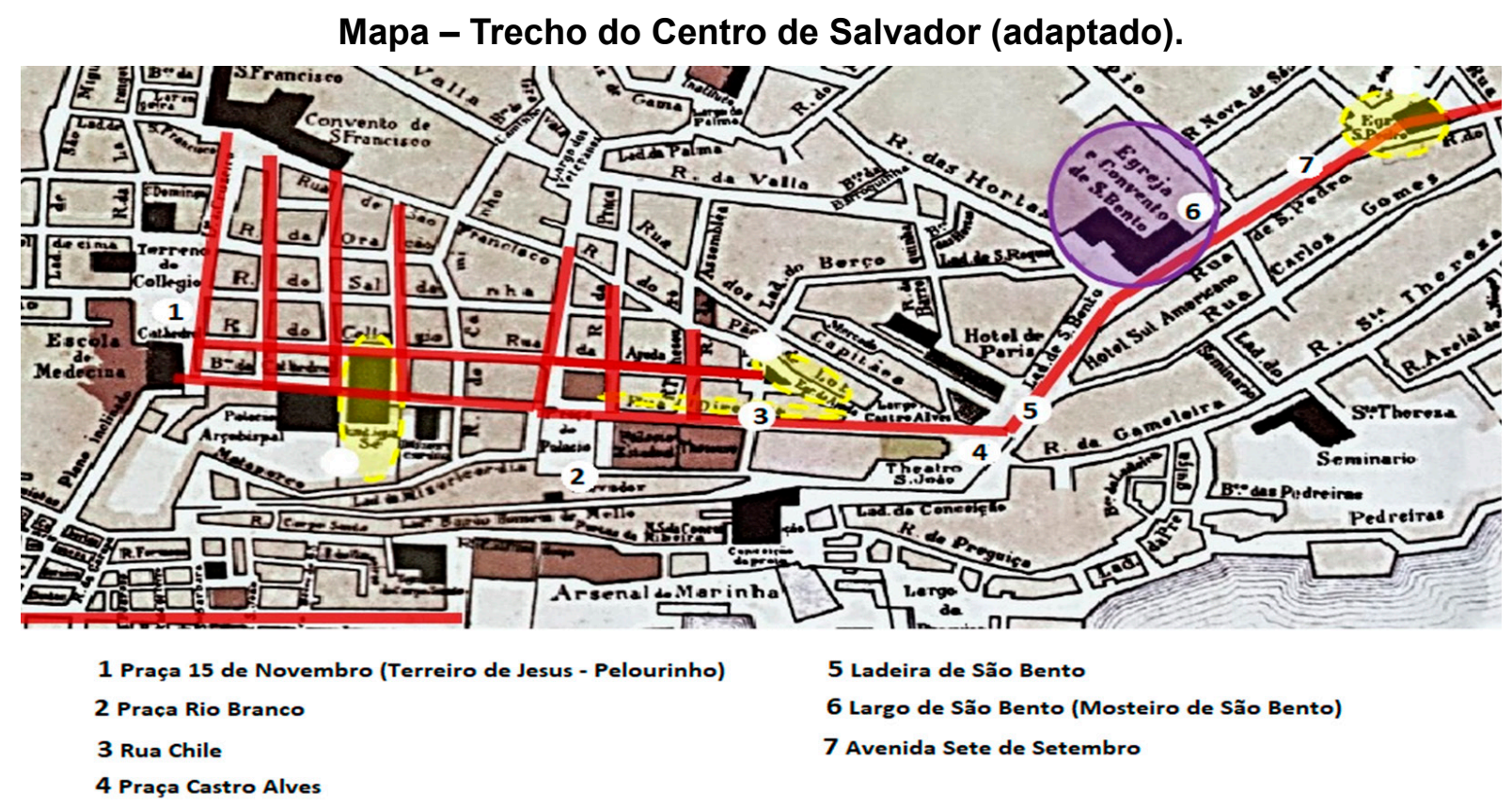

Fonte: Companhia Estadual de Desenvolvimento Urbano - CEDU, 1978. A grande Salvador: posse e uso da terra. Salvador: CEDU apud ASSUNCAO, Gabriela Lira; DANTAS, George Alexandre Ferreira. Demolições, debates e tentativas de preservação: aproximações a partir dos casos de Salvador e Recife (1910-1930). urbe. Revista Brasileira de Gestão Urbana, Curitiba, v. 10, n. 2, p. 387-399, maio-ago. 2018. p. 391.

A chamada greve geral de junho de 1919 foi a mais impactante manifestação operária de toda a I República no estado da Bahia. ${ }^{5}$ Seus significados espraiam-se para além da façanha de ter virtualmente paralisado a capital do estado - e, em acréscimo, atingir (parcialmente) certas cidades do Recôncavo. Afora ter obtido o atendimento das suas reivindicações, essa ação paredista resultou numa politização e impulso organizacional nos meios proletários baianos inéditos até então. ${ }^{6}$ De fato, aquele evento constituiu-se um ponto de inflexão no movimento operário soteropolitano. Os estudos que tratam da greve geral de 1919 frequentemente associaram a eclosão do movimento a três fatores explicativos para sua deflagração e êxito: as flutuações econômicas decorrentes da I Guerra Mundial; a crise política ocasionada pela cisão interoligárquica, em função das disputas eleitorais federais, estaduais e municipais de

5 CASTELLUCCI, Aldrin. Flutuações econômicas, crise política e greve geral na Bahia da Primeira República. Revista Brasileira de História, São Paulo, v. 25, n. 50, p. 131-166, 2005. p. 131. Para maiores informações sobre a greve geral de junho de 1919, cf.: RUBIM, A. A. C. Movimentos sociais e meios de comunicação Bahia, 1917-1921. Cadernos do CEAS, Salvador, n. 61, p. 30-43, maio-jul. 1979; RUBIM, A. A. C. \& RUBIM, J. L. C. As lutas operárias na Bahia (1917-1921). Cadernos do CEAS, Salvador, n. 80, p. 22-34, jul.-ago. 1982; FONTES, J. R. Manifestações operárias na Bahia: o movimento grevista, 1888/1930. 1988. Dissertação (Mestrado em Ciências Sociais) - Faculdade de Filosofia e Ciências Humanas, Universidade Federal da Bahia, Salvador, 1988; SANTOS, Mário Augusto da Silva. Sobrevivência e tensões sociais. Salvador (18901930). 1982. Tese (Doutorado em História) - Faculdade de Filosofia, Letras e Ciências Humanas, Universidade de São Paulo, São Paulo, 1982; CASTELLUCCI, op. cit., 2004; GUIMARÃES, Luciano de Moura. Ideias perniciosas do anarquismo na Bahia. Lutas e organização dos trabalhadores da construção civil (Salvador, 1919-1922). 2012. Dissertação (Mestrado em História Social) - Faculdade de Filosofia e Ciências Humanas, Universidade Federal da Bahia, Salvador, 2012.

6 CASTELLUCCI, op. cit., 2004, p. 150-151. 
$1919 ;{ }^{7}$ e as transformações operadas na própria organização sindical e política do movimento operário baiano, com a fundação e reativação de diversos sindicatos de resistência. Pela primeira vez no estado, figurou no rol de reivindicações operárias questões como duração da jornada de trabalho, reconhecimento do direito de associação, isonomia salarial entre homens e mulheres que exercessem as mesmas funções e abolição do trabalho infantil. Até então, predominavam as lutas visando aumentos salariais, através de greves isoladas por unidade de produção. Com a greve geral, o movimento operário passou a abranger muito mais estabelecimentos e trabalhadores, contestando, inclusive, "os mecanismos de compra e venda da força de trabalho". ${ }^{8}$ Foi no bojo desse processo, que se distinguiu a associação dos operários da construção civil, o SPCDC, como a organização mais atuante e presente nas lutas e manifestações do contexto, marcado pela intensificação do associativismo sindical. As lideranças surgidas nesse sindicato foram as principais responsáveis pela eclosão e êxito da greve geral, assim como pelo decorrente incremento organizacional e político que atingiu o movimento operário baiano naquela conjuntura.

Figura 1 - Grevistas nas jornadas de junho de 1919.

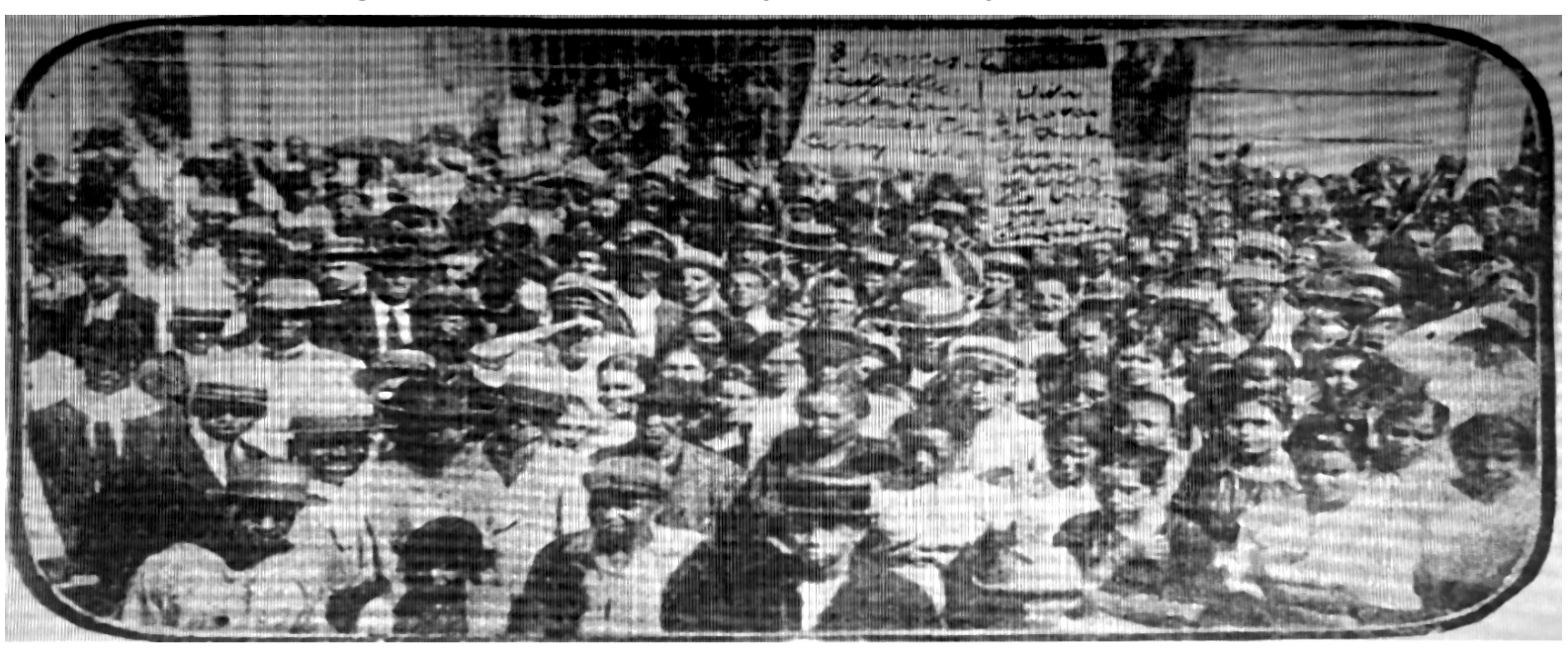

Fonte: A Tarde, Salvador, 4 jun. 1919. (Biblioteca Pública do Estado da Bahia).

Fundado poucos meses antes da greve geral, o Sindicato dos Pedreiros, Carpinteiros e Demais Classes veio a ser um nó resoluto de articulação da parede, sendo o responsável por iniciá- la, generalizá-la e, ao lado dos outros sindicatos, de orientá-la e sustentá-la até o atendimento das exigências - jornada de oito horas de trabalho e aumento salarial. Ademais, no período que se seguiu, o SPCDC se revelaria cada vez mais presente. Participou e apoiou

7 Sobre as disputas políticas na Bahia da I República, ver, entre outros: SAMPAIO, Consuelo. Partidos políticos da Bahia na Primeira República: uma política de acomodação. Salvador: EDUFBA, 1998; SARMENTO, Sílvia N. A raposa e a águia. J. J. Seabra e Ruy Barbosa na Política Baiana da Primeira República. Salvador: EDUFBA, 2011; CUNHA, Joaci de Souza. O fazer político da Bahia na República Velha. 2011. Tese (Doutorado em História) - Faculdade de Filosofia e Ciências Humanas, Universidade Federal da Bahia, Salvador, 2011.

8 CASTELLUCCl, op. cit., 2004, p. 37. 
novas greves, como a dos têxteis, em setembro do mesmo ano e a da construção civil, em princípios de 1920. Articulou o Primeiro Congresso de Trabalhadores Baianos, em julho de 1919, e colaborou decisivamente na criação da Federação dos Trabalhadores Baianos (FTB) em fevereiro de 1920. Sua atividade contou, ainda, com a publicação de dois jornais operários - Germinal, 1920, e A Voz do Trabalhador, 1920-1922. Também se encarregou da fundação de uma escola proletária nos moldes da Escola Moderna, segundo a proposta pedagógica racionalista do educador catalão Francisco Ferrer (Grupo Escolar Carlos Dias).

\section{Os operários da construção civil de Salvador}

COM CARACTERÍSTICAS TOTALMENTE DIFERENTES das atuais, a construção civil se destacava entre os ramos semiartesanais pelo nível instrucional relativamente mais alto dos operários, pela maior articulação e continuidade organizativa. ${ }^{9}$ Como explicam Gitahy e Silva, focalizando o caso santista, isto se devia à conjugação de dois fatores. O primeiro refere-se ao processo de trabalho no ramo de edificações, que demandava um número significativo de trabalhadores qualificados. Estes operários mantinham uma posição mais favorável no mercado de trabalho em relação aos trabalhadores da construção pesada e da infraestrutura urbana, operários "sem ofício", com baixa qualificação. ${ }^{10} \mathrm{O}$ segundo fator diz respeito à estruturação dos negócios dessa indústria. A descrição de Maram, para os casos do Rio de Janeiro, São Paulo e Santos, parece coadunar-se com a situação baiana. Como usualmente as construções eram realizadas por encomenda e não havia o predomínio de grandes empresas construtoras, o ramo dividia-se principalmente entre muitos pequenos e médios empreiteiros e mestres de obras. Além dessa atomização patronal, os empregadores geralmente assumiam contratos com prazos predeterminados para a entrega do serviço e com pagamento a receber apenas ao término da obra. Normalmente também se responsabilizavam pelos custos de material e pessoal durante a consecução das construções. Isto conferia um razoável poder de barganha dos trabalhadores frente aos empreiteiros, quando de uma paralisação mais prolongada. $\mathrm{O}$ risco de ter que arcar com todas as despesas em caso de atraso na entrega do serviço, em geral instigava os construtores a resolver brevemente suas questões com os operários. Ademais, de acordo com Maram,

era comum o empreiteiro, ao contrário do que acontecia com o grande empregador de trabalho industrial não qualificado, não conseguir substituir seus operários durante uma greve, pois nas épocas de prosperidade havia uma alta procura e uma baixa oferta dos trabalhadores qualificados em construção, especialmente os tão essenciais pedreiros (...). As greves nessa indústria costumavam dar bons resultados. ${ }^{11}$

9 FAUSTO, Boris. Trabalho urbano e conflito social (1890-1920). São Paulo: Difel, 1976. p. 129.

10 SILVA, Fernando T. da; GITAHY, Maria Lúcia C. O movimento operário da construção civil de santista durante a Primeira Guerra Mundial (1914-1918). História Social, Campinas, n. 3, p. 89-90, 1996.

11 MARAM, Sheldon Leslie. Anarquistas, imigrantes e o movimento operário brasileiro (1890-1920). Rio de Janeiro: Paz e Terra, 1979. p. 51-52. 
Portanto, a qualificação profissional conjugada à existência de muitos pequenos empreiteiros teria proporcionado aos trabalhadores do setor de edificações certa "continuidade organizativa e combatividade". ${ }^{12}$ Tratando dos trabalhadores desse subsetor da construção civil de Santos, das primeiras décadas do século XX, Silva nos confirma que a categoria gozava de privilegiada posição em relação aos que labutavam em outros ofícios. Eram operários com qualificação, que se reputavam "artistas", e que gozavam de "relativa independência", possibilitando um grau de "mobilidade e desenvoltura", que não se verificava nas grandes unidades fabris. ${ }^{13}$ Muitos deles, proprietários de seus instrumentos de trabalho: martelos, colheres, prumos e formões, entre outros.

O ramo de edificações da construção civil "contribuiu com os organizadores e ativistas do movimento operário" ao longo de toda a I República, não apenas em Santos, como no Rio de Janeiro e São Paulo. ${ }^{14}$ No mesmo período, também no Rio Grande do Sul, os sindicatos dos trabalhadores da construção civil foram fundamentais na organização do movimento operário. ${ }^{15}$ Fora do Brasil, os trabalhadores desse setor igualmente se sobressaíram como ativos militantes no movimento operário francês, ao ocuparem "lugar de primeiro plano na CGT", constituindo federações importantes, além disto, em países como Portugal, Países Baixos, Alemanha, Suécia e Grã-Bretanha. ${ }^{16}$ Para o caso baiano, contudo, Fontes, em seu estudo sobre as greves operárias da I República na Bahia, pondera que houve um número relativamente "baixo" de paralisações de trabalho, envolvendo uma "categoria que era considerada vanguarda do movimento operário em vários centros". Entretanto, o autor destaca a importância que o sindicato da categoria, o SPCDC, assumiu na conjuntura 1919-1921. ${ }^{17}$

Dessa forma, combatividade e continuidade organizativa operárias, derivadas do processo de trabalho e da qualificação profissional, presentes também na cultura desses trabalhadores, não devem ser tomadas como uma relação estritamente causal. Na Bahia, apesar da presença desses dois fatores, as organizações de trabalhadores da construção civil foram efêmeras, assim como sua combatividade. Nesse sentido, a experiência histórica do SPCDC pode ser vista muito mais como uma exceção, do que como exemplo ordinário de um padrão. Do mesmo modo, depreender a orientação ideológica predominante na categoria profissional da construção civil, com base naqueles mesmos fatores, mostra-se inadequado para o caso soteropolitano. A opção preferencial pelo sindicalismo de ação direta, presente nas organizações congêneres de outras regiões do país (como Santos, São Paulo e Rio, por exemplo) e do mundo, não estava no horizonte do SPCDC, pelo menos em relação ao

12 SILVA, Fernando Teixeira. Operários sem patrões: os trabalhadores de Santos no entreguerras. Campinas: Editora da Unicamp, 2003. p. 53.

13 Ibidem, p. 52-53.

14 GITAHY, Maria Lúcia Caira. Ventos do mar: trabalhadores do porto, movimento operário e cultura urbana. São Paulo, Editora da Universidade Estadual Paulista, 1992. p. 119-120.

15 MARAM, op. cit., p. 53.

16 SILVA, op. cit., p. 61.

17 FONTES, op. cit., p. 68. 
período compreendido entre a sua fundação e o estalar da greve geral, em junho de $1919 .{ }^{18} \mathrm{~A}$ imponderabilidade da história, somada ao poder criador dos sujeitos históricos - que podem responder distintamente às mesmas situações, assim como "criar novas situações" - sugere que não se deve pensar a história segundo um determinismo que nega justamente este poder criador. ${ }^{19}$ Assim, talvez não seja o mais adequado deduzir o comportamento desses trabalhadores com base numa relação de causalidade.

Observando o campo de trabalho da construção civil em Salvador, percebemos que ele detinha considerável importância na economia local, absorvendo expressivo contingente da população masculina operária da capital. $^{20}$ Os trabalhadores dessa categoria, que normalmente iniciavam-se nas artes do ofício no princípio da adolescência, às vezes ainda na infância, assumiam primordialmente as funções de mestres, pedreiros, carpinteiros, pintores e serventes. Os pedreiros e carpinteiros, em especial, eram bastante requisitados, pois, como explica Freire, apenas eles detinham "a concepção global do projeto e da obra acabada; só eles dominam com facilidade as operações mentais de transposição da representação do papel, em plano, para a realidade", além de serem os únicos que detinham "noções quantificadas das dimensões, formas e volumes". ${ }^{21}$ Assim, entre esses trabalhadores qualificados, em especial aqueles que trabalhavam no ramo de edificações - como os já citados pedreiros, carpinteiros, além dos pintores, frentistas, marmoristas, entre outros -, havia um número menor de analfabetos, pois, graças à natureza de sua ocupação, nutriam certo gosto pela leitura, além de considerarem-se "artistas", devido à capacidade técnica e habilidade requeridas pelos seus ofícios. ${ }^{22}$ As construções maiores podiam empregar também uma gama variada de ocupações, mais ou menos especializadas, tais como vigias, ferreiros, apontadores, eletricistas, jardineiros, estucadores, mecânicos, contramestres, ajudantes, entre outras. ${ }^{23}$

Por outro lado, esses operários enfrentavam um mercado de trabalho marcado pela irregularidade, o que gerava uma elevada rotatividade de mão de obra, oscilante ao sabor da flutuação de crescimento urbano experimentado por Salvador. ${ }^{24}$ Isto fazia do governo do

18 Apoiando-se nos argumentos de Marcel van der Linden e Wayne Thorpe, Fernando Teixeira da Silva afirma que "o apelo à ação direta teve forte audiência entre os trabalhadores da construção civil em razão da natureza de seu ofício e à forma pela qual estava organizada a indústria desse setor". Assim, o pesquisador considera que o exercício de "atividades profissionais episódicas, frequentes mudanças de empregadores, de local de trabalho, e, por vezes, de residência constituíam fatores não desprezíveis para a adesão às formas de luta fundadas na ação direta". Cf.: SILVA, op. cit., p. 61.

19 CASTORIADIS, Cornelius. A instituição imaginária da sociedade. Rio de Janeiro: Paz e Terra, 1982. p. 58.

20 Segundo o Censo Populacional de 1920, os 8.753 operários da categoria correspondiam a $19,2 \%$ da classe trabalhadora de Salvador, ficando atrás apenas do setor de vestuário e toucador, que absorvia $49,2 \%$ do operariado da capital do estado. Ver: CASTELLUCCI, op. cit., 2004, p. 60, tabela 2.

21 FREIRE, João. Anarquistas e operários. Ideologia, ofício e práticas sociais: o anarquismo e o operariado em Portugal, 1900-1940. Porto: Afrontamento, 1992. p. 87-89 apud SILVA, op. cit., p. 54.

22 GITAHY, op. cit., p. 119; SILVA, Fernando Teixeira. "Artistas", anarquistas e declínio do sindicalismo de ação direta em Santos. História, São Paulo, v. 21, p. 102, 2002. p. 102. O processo pelo qual, na Bahia, os termos "artista" e "operário" passaram a designar, genericamente, o mesmo conceito, foi descrito por Maria das Graças de Andrade Leal. Cf.: A arte de ter um ofício: Liceu de Artes e Ofícios da Bahia. Salvador: Fundação Odebrecht, 1996, principalmente o capítulo 2.

23 SANTOS, op. cit., p. 56.

24 SANTOS, Mário Augusto da Silva. A república do povo: sobrevivência e tensão - Salvador (1890-1930). 
estado, por ser patrocinador e idealizador de empreendimentos que arrasaram e reergueram quarteirões, ou que também podiam ser obras de aterramento para novas construções, o maior contratador de obras e, consequentemente, o maior empregador em tempos de dificuldades financeiras. Segundo relatório da Secretaria de Agricultura, Indústria, Comércio, Viação e Obras Públicas, relativo ao ano de 1920, esta era exatamente a situação vivida pela Bahia, que vinha sofrendo os efeitos "determinantes de uma crise, incontestavelmente, de caráter geral". ${ }^{25}$ Crise essa que incidiu mais profundamente no mercado de trabalho da construção civil justamente no intervalo entre 1919 e 1921, quando foi registrado o pior índice de crescimento predial (obras particulares) em Salvador durante a I República. ${ }^{26}$ Talvez faça sentido, então, o fato de que, em 1921, a maioria dos associados do SPCDC se concentrasse "na obra do Tesouro do Estado". ${ }^{27}$

Portanto, com parcos investimentos privados no setor responsável pela construção e reparos de edifícios residenciais e comerciais, uma solução mais viável para escapar da desocupação era empregar-se nas obras públicas, do município e do estado, uma vez que usualmente utilizavam uma gama maior de funções, atuando na construção de edifícios, aberturas, alargamentos, cortes e calçamentos de ruas e avenidas, canalização de águas e esgotos, implantação de iluminação, além de outros serviços urbanísticos. ${ }^{28}$ Entretanto, o ritmo dessas construções também oscilava de acordo com a condição das finanças públicas, nem sempre robustas, reforçando o caráter ocasional do trabalho. Como o município passou por crises financeiras durante boa parte da I República, não era muito extenso nem regular o campo de oportunidades de trabalho proporcionado pela municipalidade - ainda que significativo diante de um mercado que deixava de oferecer muitas opções quando dos anos de retração. Em contrapartida, o estado contribuiu com maior regularidade para o setor da construção civil. ${ }^{29}$

Em 1919 deu-se a continuidade de algumas obras enquanto iniciaram-se outras. Mas, a partir de 1920, o ritmo voltou a cair para recuperar-se somente em 1923. Com efeito, a irregularidade de oportunidade de trabalho na construção civil pode ser observada nas obras do próprio governo estadual, cujo número de operários empregados variava anualmente, mensalmente, "de uma obra para outra e até dentro da mesma obra". ${ }^{30}$ Não obstante, durante o governo Antônio Moniz (1916-1920), realizaram-se muitas obras públicas. Algumas das mais importantes foram a reconstrução do Palácio Rio Branco, o término da construção da ala principal do Palácio da Aclamação, a construção dos edifícios da Biblioteca Pública e do

Salvador. EDUFBA, 2001. p. 25.

25 Relatório dos serviços da Secretaria de Agricultura, Indústria, Viação e Obras Públicas durante o ano de 1920. Arquivo Público do Estado da Bahia, Documentação da Secretaria da Agricultura, Indústria e Comércio, caixa 2386 , maço 180 , doc. 760.

26 SANTOS, op. cit., p. 58, quadro $X$

27 MARINHO, Eustachio. Um protesto. A voz do trabalhador, Salvador, 5 fev. 1921.

28 SANTOS, op. cit., p. 56-57.

29 Ibidem, p. 62-65.

30 Ibidem, p. 68. 
Tesouro do Estado, além do início da abertura de estradas de rodagem, ${ }^{31}$ e a conclusão de algumas obras herdadas do governo anterior, de J.J. Seabra, como a avenida Oceânica, por exemplo, ligando o bairro da Barra até o do Rio Vermelho.

Figura 2 - Reconstrução do Palácio Rio Branco (1919). À esquerda, a rua Chile.

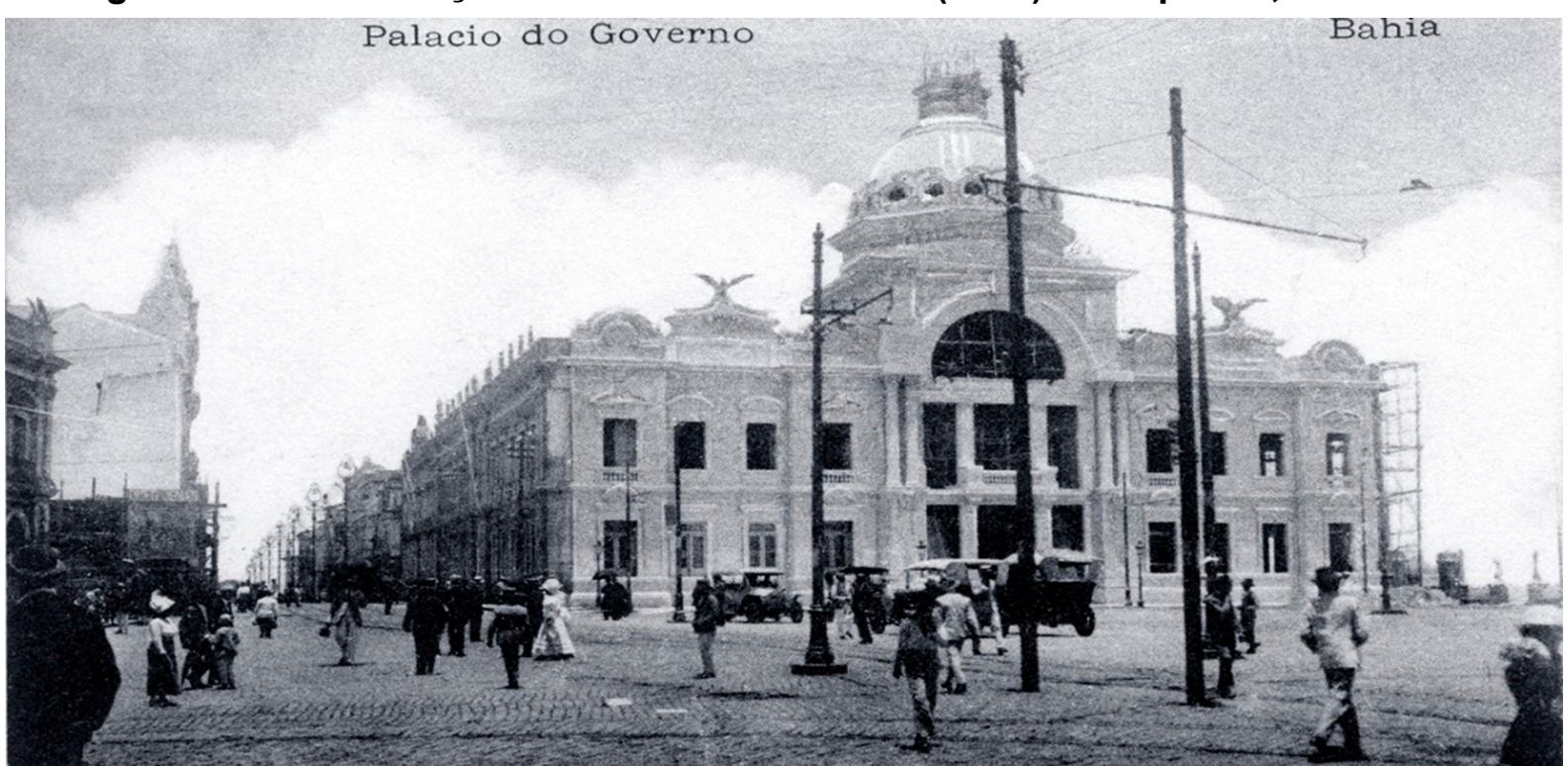

Fonte: http://www.salvador-turismo.com/praca-thome-sousa/antigas/construcao.htm. Acesso em: 25 jun. 2020.

Uma vez empregado numa dessas obras, o operário teria que lidar com jornadas de trabalho extensas, salários comprimidos e falta de segurança laboral. Apenas alguns dias depois da fundação do SPCDC, José dos Santos Gomes, fiscal e orador da entidade, sentiu na carne a experiência de passar por um acidente de trabalho. Ele trabalhava nas obras de construção da Biblioteca Pública do Estado da Bahia, localizada na praça Rio Branco, centro político-administrativo da cidade, quando foi "vítima de um acidente" que lhe feriu a mão direita, tendo sido atendido pela "Assistência". ${ }^{2}$ Para aqueles que não se acidentassem restava receber em torno de $4 \$ 000$ a $5 \$ 000$ diários, se oficial pedreiro ou carpinteiro e $1 \$ 500$ a $2 \$ 500$ no caso dos serventes. Isso cumprindo uma jornada não inferior a dez horas de trabalho por dia. ${ }^{33} \mathrm{~A}$ defasagem entre preços e salários parecia ser especialmente intensa nos primeiros meses de 1919. A carestia dos gêneros alimentícios de primeira necessidade atingia até mesmo setores da classe média, que estariam passando "as maiores necessidades". De acordo com o periódico O Tempo, na Bahia de então, "só os ricos podem viver", pois "as classes proletárias sofrem horrores" com a "exagerada alta" de alimentos e vestuário. Somada à questão inflacionária, a especulação dos comerciantes apertava ainda mais o laço

31 ARAGÃO, Antônio F. Moniz de. A Bahia e seus governadores na República. Edição fac-similar comemorativa aos 120 anos da Proclamação da República na Bahia. Salvador: Fundação Pedro Calmon; UEFS Editora, 2010. p. 691.

32 Jornal de Notícias, Salvador, 22 mar. 1919.

33 Germinal, 19 mar. 1920; A Voz do Trabalhador, 2 out. 1920; SANTOS, op. cit., p. 93-101. 
sobre largos contingentes da população que, "arrastada pela usura dos açambarcadores", encontrava-se "quase nos limites da fome". ${ }^{34}$ Pedreiros e carpinteiros, empregados da Casa Pia e Colégio dos Órfãos de São Joaquim, percebiam $5 \$ 000$ de diária em 1919. No mesmo período, os preços dos alimentos foram majorados numa razão de mais de $100 \%$ em relação aos salários daqueles operários. ${ }^{35}$

Podemos verificar mais de perto o grau da defasagem entre preços e salários. O periódico A Tarde, ao apoiar as reivindicações dos trabalhadores da construção civil, nos primeiros dias da greve geral, salientava que "nas obras públicas do Estado, o operário trabalhava de sol a sol, vencendo as mesmas diárias de antes da guerra". ${ }^{36}$ Em outro momento, por ocasião da greve parcial dos trabalhadores da construção civil, que durou 58 dias, desde meados de janeiro até 19 de março de 1920, o SPCDC formulou uma lista com a receita e as despesas diárias de um servente de pedreiro. Para uma receita de $3 \$ 000$, por oito horas de trabalho, aqueles operários, considerando sustentarem uma família de cinco pessoas, arcariam com uma despesa de $9 \$ 860$, incluindo gastos com alimentação, higiene doméstica e moradia. ${ }^{37} \mathrm{Em}$ março de 1921, a situação não parecia ser muito diferente. Segundo o que propalava o jornal do SPCDC, $A$ Voz do Trabalhador, "em consequência dos salários serem reduzidíssimos, em comparação aos elevadíssimos preços dos gêneros de primeira necessidade", os trabalhadores da construção civil estavam almoçando "pão e laranja" ${ }^{38}$

Uma especificidade da capital baiana em relação à composição de seu mercado de trabalho, e que obviamente diz respeito ao campo da construção civil, é que, ao contrário de outras regiões do país, notadamente seu Sudeste e Sul, a mão de obra em Salvador era basicamente afrodescendente e nacional, e continuou, na I República, a "desempenhar as mesmas ocupações de épocas pretéritas". ${ }^{39}$ Vale a pena determo-nos nesse ponto. Estudando os cantos ${ }^{40}$ dos ganhadores às vésperas da abolição, Reis informa que muitos deles exerciam ofícios distintos daqueles específicos do canto - basicamente, transporte de mercadorias. Segundo o historiador, as atividades ligadas à construção civil eram praticadas por expressivo número de ganhadores, livres e libertos, empregados nos cantos de Salvador, no período pré-abolição. Em um universo de 1.703 trabalhadores registrados na matrícula de 1887, quase metade declarou ter outra ocupação profissional. Destes, 57,2\% disseram trabalhar

34 O Tempo, Salvador, 17 mar. 1919.

35 SANTOS, op. cit., p. 121 (Quadro XV - A) e p. 332 (Quadro XXIX - D).

36 A Tarde, Salvador, 4 jun. 1919.

37 Diário de Notícias, Salvador, 12 fev. 1920. A lista aludida era assim constituída: "Por dia: Despesa - (almoço de pão); $1,2 \mathrm{~kg}$ de pão, $\$ 400,250 \mathrm{~g}$ de açúcar, $\$ 360,100 \mathrm{~g}$ de café, $\$ 300$, carvão, $\$ 200$, leite para o pequeno, $\$ 200$, soma $1 \$ 460$. - Jantar às 12 horas: $1 \mathrm{~kg}$ de carne verde, $1 \$ 400$, toucinho, $\$ 200,1$ litro de feijão, $\$ 400$, 3 litros de farinha, $\$ 900$, temperos, $\$ 500$, carvão, $\$ 300,250 \mathrm{~g}$ de charque, $\$ 700$, soma $4 \$ 400$. - Higiene doméstica: $1,2 \mathrm{~kg}$ de sabão, $\$ 400,4$ barris d'água, $\$ 400$, anil, $\$ 100,2$ feixes de lenha, $\$ 600$, soma $1 \$ 500$. - Ceia: $1,2 \mathrm{~kg}$ de pão, $\$ 400,100 \mathrm{~g}$ de café, $\$ 300$, carvão, $\$ 200$; bonde $\$ 200$, cigarros e fósforos, $\$ 300,1,2$ litros de gás, $\$ 120$, aluguel de casa, $1 \$ 000$, soma $2 \$ 500$. - Receita: dia normal de oito horas, $3 \$ 000$; despesas gerais, 9\$860; deficit, 6\$860".

38 A Voz do Trabalhador, Salvador, 5 mar. 1921.

39 CASTELLUCCI, op. cit., 2004, p. 73-75 e p. 77-79.

40 Cantos eram grupos de trabalho urbano que reuniam ganhadores (escravos e livres, de diversas cores), organizados a partir das identidades étnicas. 
em ofícios tipicamente pertencentes à construção civil, sendo que os pedreiros em particular correspondiam à aproximadamente metade desse montante..$^{41} \mathrm{De}$ acordo com Reis, esse fenômeno de dupla ocupação se explicava pelo caráter intermitente das atividades ligadas à construção civil, o que também ocorria com os carregadores; isto "facilitava a combinação entre os dois místeres". Formado por extrema maioria de negros e afrodescendentes nacionais, muitos deles ex-escravos ${ }^{42}$ como mencionado, vários cantos transformaram-se em "verdadeiras turmas de construção e seus capitães verdadeiros empreiteiros de obras". ${ }^{43}$ Observamos, dessa forma, uma permanência onde, possivelmente, o século XIX informou o século XX no processo do fazer-se da classe operária baiana. Uma vez que o aprendizado dos ofícios ligados à construção civil iniciava-se no princípio da adolescência ou ainda na infância ${ }^{44}$ é plausível propor que os trabalhadores dessa categoria profissional de Salvador, na conjuntura em questão, apresentassem traços de uma cultura étnico-profissional, legados pelas suas experiências laborais do pré-abolição.

\section{O SPCDC e a greve geral}

COM ALGUMA EXPERIÊNCIA ORGANIZATIVA, os operários da construção civil de Salvador estavam reunidos em sindicato desde 1905, quando foi criada a Associação Defensora dos Trabalhadores em Construção, e já haviam feito greves por melhores salários em novembro de 1913 e fevereiro de 1914, quando se associavam na Sociedade Defensora dos Pedreiros. ${ }^{45}$ Fundado por 25 trabalhadores, ${ }^{46}$ em 19 de março de 1919, dia de São José, padroeiro dos carpinteiros, o SPCDC estabeleceu sua primeira sede no Beco do Mota, no distrito central da Sé, na área até hoje conhecida como Maciel, então habitada por muitos trabalhadores, negros principalmente, e endereço de diversas associações operárias. ${ }^{47}$ Convém destacar que parte dos primeiros membros do SPCDC trazia alguma experiência organizativa anterior. Como comprovou Castellucci, cinco operários que se filiaram ao sindicato em 1919 haviam integrado o Centro Operário da Bahia. Eram eles Abílio José dos Santos, Manoel do Bonfim Antunes, Victorino de Sant'Anna Muricy, todos pedreiros e fundadores do sindicato, e os marceneiros José Domiense da Silva e Manoel Quintino dos Santos, este também fundador da entidade. Assim, sua hipótese é que o Centro Operário, que chegou a contar com mais de 5 mil membros em 1894 - e que em 1919 computava 1,2 mil associados -, estaria perdendo militantes para os sindicatos de resistência reativados ou fundados na conjuntura 1919-

41 REIS, João José. De olho no canto: trabalho de rua na Bahia na véspera da abolição. Revista Afro-Ásia, Salvador, n. 24, p. 199-242, 2000. p. 242.

42 Reis, esclarece que naquele momento, de franca decadência da escravidão, o número de escravos empregados nos cantos reduzira-se a "quase nada".

43 REIS, op. cit., 212-234.

44 SANTOS, op. cit., p. 23

45 CASTELLUCCI, op. cit., 2004, p. 143.

46 ESTATUTOS do Sindicato dos Pedreiros, Carpinteiros e Demais Classes. Diário Oficial do Estado da Bahia, Salvador, 19 out. 1919.

47 CASTRO, José Guilherme da C. (org.). Miguel Santana. Salvador: EDUFBA, 1996. p. 15-41. 
1921.48 Isto é um forte indício de que, naquele momento, a opção pela organização em moldes sindicais tornava-se interessante para muitos trabalhadores de Salvador.

O SPCDC distinguia-se do Centro Operário, que possuía muitos artesãos qualificados em suas fileiras, grande parte ligada aos ofícios da construção civil, por abrigar em seu seio apenas trabalhadores manuais assalariados. Era vedada a participação dos mestres e contramestres ou de qualquer um que não tivesse extração operária. Além disso, ao contrário do Centro Operário, buscava organizar aqueles trabalhadores sem qualificação profissional, como os ajudantes e serventes, sem espaço nas associações existentes. ${ }^{49}$ Esses operários ditos "sem ofício" estavam submetidos a penosas condições de trabalho devido à intensa concorrência entre esse tipo de mão de obra. ${ }^{50}$ De acordo com Batalha, os sindicatos por ofício eram a forma mais comum de organização operária até a metade dos anos 1910 , afiliando usualmente os profissionais mais qualificados e/ou com maior tradição organizativa. Citando o caso dos operários da construção civil, afirma que pedreiros e carpinteiros, por exemplo, possuíam sindicatos próprios, enquanto serventes e ajudantes, mão de obra com baixa qualificação, ficavam na dependência de que fosse criado um sindicato de indústria ou por ramo de atividade que os absorvesse. ${ }^{51}$

A opção do SPCDC em filiar serventes e ajudantes encontra paralelo em outro caso. Uma das características mais marcantes das organizações dos trabalhadores da construção civil, afirma Silva, voltando-se para o caso santista da I República, é sua tendência à "amalgamação" dos distintos ofícios da profissão numa mesma organização. "Os trabalhadores da construção", prossegue, "não se limitaram a defender seus próprios interesses", mas tentaram organizar e apoiar "todo o movimento operário santista" ${ }^{52}$ Pelas páginas do periódico Germinal, publicado pelo SPCDC entre março e abril de 1920, podemos perceber que isto também se observava em relação ao caso baiano. Em seu entorno muitas associações se reuniram e organizaram. Os marceneiros, por exemplo, só criaram sua associação própria, o Sindicato dos Produtores de Marcenaria, em julho de 1919 (até então faziam parte da mesma associação que os pedreiros e carpinteiros). Nesse ínterim, continuaram a reunir-se na sede do SPCDC até o início de maio de 1920, pelo menos. E não eram somente os marceneiros que utilizavam a sede dos Pedreiros e Carpinteiros para abrigar suas reuniões: segundo o Germinal, também os sapateiros da Sociedade União Defensora dos Sapateiros e a própria Federação dos Trabalhadores Baianos (FTB), fundada em fevereiro de 1920, o fizeram. ${ }^{53}$

48 CASTELLUCCI, Aldrin. Trabalhadores, máquina política e eleições na Primeira República. Tese (Doutorado em História) - Faculdade de Filosofia e Ciências Humanas, Universidade Federal da Bahia, Salvador, 2008. p. 141-142.

49 Como aponta Castellucci, não interessava ao Centro Operário, cuja diretriz era interferir no jogo político institucional, isto é nas eleições, admitir como membros pessoas que não gozassem do direito ao voto, caso dos ajudantes e serventes, em geral analfabetos. Cf.: CASTELLUCCI, op. cit., 2008, p. 129.

50 SILVA; GITAHY, op. cit., p. 89-90.

51 BATALHA, Claudio H. M. O movimento operário na Primeira República. Rio de Janeiro: Editora Jorge Zahar, 2000. p. 17.

52 SANTOS, Operários sem patrão, op. cit., p. 52-53.

53 Germinal, Salvador, 19 mar. 1920. 
A preocupação das lideranças do SPCDC em organizar categorias sem representação sindical era observada pelo seu apoio à abertura de novos grêmios, como fizeram em Nazaré das Farinhas, no Recôncavo, onde, em agosto de 1919, fundaram a sucursal União dos Pedreiros Nazarenos, e em Muritiba, também em agosto de 1919, com a fundação do Comitê da Defesa Operária, entidade "confederada" à associação dos pedreiros e carpinteiros de Salvador. ${ }^{54}$ Ou ainda quando auxiliaram a criação da Sociedade União e Amparo de Todas as Classes, em junho de $1920 .{ }^{55}$ Cabe destacar que tal esforço não se restringia aos trabalhadores urbanos. Em matéria memorialística, o jornal comunista O Momento, publicado em Salvador no breve período de abertura política verificado após o término da Segunda Guerra Mundial, informa que o sindicato enviou alguns representantes "para organizar os trabalhadores agrícolas da llha de Maré". Após realizarem algumas reuniões "a comissão de operários sindicalistas" teria sido "escorraçada da ilha pelos proprietários" de terras. ${ }^{56} \mathrm{De}$ fato, em agosto de 1920, um Sindicato de Ofícios Vários foi fundado naquela localidade, "sob influência direta de Agripino Nazareth", advogado do SPCDC e uma importante liderança na conjuntura 1919-1921. ${ }^{57}$ Foram esses trabalhadores, menos de três meses depois de criada sua associação de classe, os responsáveis pela paralisação que daria origem a greve geral de junho de 1919.

No dia 1 de junho, um domingo, realizou-se, a convite do SPCDC, uma reunião em sua sede, para a qual haviam sido convidadas pelas páginas de vários órgãos da imprensa "todas as classes de trabalhadores terrestres e marítimos, ferroviários, metalúrgicos, foguistas, marinheiros e todos os trabalhadores sem distinção de classe", para tratarem de interesses em comum. O convite ressaltava que a conferência sindicalista permitiria àqueles trabalhadores "conhecer o caminho" pelo qual se libertariam "das misérias que vos traz o jugo patronal". Assinavam o convite, sob vivas ao proletariado internacional e à organização operária, Guilherme Francisco Nery, presidente, Antônio Amaro de Sant'Anna, secretário, Abílio José dos Santos, tesoureiro e José dos Santos Gomes, fiscal. ${ }^{58}$

A conferência sindicalista teve como principal orador o advogado socialista Agripino Nazareth, baiano de nascimento, vindo do Rio de Janeiro e restabelecido em Salvador após participação numa tentativa revolucionária na capital federal, conhecida como Insurreição Anarquista de $1918 .^{59}$ Nazareth tornaria-se, daquele momento em diante, a liderança mais influente nos meios proletários baianos, até sua deportação de volta ao Rio, em 28 de janeiro

54 CASTELLUCCI, op. cit., 2004, p. 177-178; O Imparcial, Salvador, 16 ago. 1919.

55 A Voz do Trabalhador, Salvador, 18 jun. 1921.

56 O Momento, Salvador, 9 abr. 1945.

57 CASTELLUCCI, op. cit., 2004, p. 236.

58 O Tempo, Salvador, 1 jun. 1919; Diário da Bahia, Salvador, 1 jun. 1919; O Imparcial, Salvador, 31 maio e 1 jun. 1919.

59 Sobre a Insurreição Anarquista, cf.: ADDOR, Carlos Augusto. A Insurreição Anarquista no Rio de Janeiro. Rio de Janeiro: Dois Pontos, 1986; NÉBIAS, Wellington Barbosa. A greve geral e a A Insurreição Anarquista de 1918 no Rio de Janeiro: um resgate da atuação das associações de trabalhadores. 2009. Dissertação (Mestrado em História Comparada) - Universidade Federal do Rio de Janeiro, Instituto de Filosofia e Ciências Sociais, Rio de Janeiro, 2009. 
de 1921, na esteira dos desdobramentos de uma greve dos têxteis, severamente reprimida pela polícia. O levante de novembro de 1918, no qual Nazareth havia se engajado juntamente com diversas lideranças anarquistas, a exemplo de José Oiticica, Astrojildo Pereira, Manuel Campos, João da Costa Pimenta, Álvaro Palmeira, José Elias da Silva e Carlos Dias, tinha o objetivo de implantar uma República de Operários e Soldados no Brasil, de caráter soviético. ${ }^{60} \mathrm{~A}$ revolta, que ocorreu paralela à eclosão de greves entre metalúrgicos, operários da construção civil e têxteis, foi sufocada em seu nascedouro, após a delação de um tenente do Exército, infiltrado entre os insurretos. As forças policiais efetuaram, então, centenas de prisões e deportações, além de promoverem o fechamento das associações operárias daquelas categorias grevistas, o que provocou uma "diáspora" de militantes e trabalhadores envolvidos no acontecido. ${ }^{61}$ Talvez prevendo essa possibilidade, o periódico baiano O Imparcial, de 23 de janeiro de 1919, divulgou que o secretário de Polícia ordenara ao inspetor de Polícia do Porto que impedisse o desembarque de "indesejáveis" em Salvador, a exemplo de "cáftens, ladrões e anarquistas". ${ }^{62}$

Cumpre destacar que a Insurreição Anarquista ocorreu num contexto de intensificação das lutas operárias verificadas na conjuntura 1917-1920, quando expectativas de transformação radical da sociedade foram compartilhadas por importantes parcelas da classe operária em nível nacional. Greves gerais foram desencadeadas em várias cidades brasileiras: São Paulo (1917); Rio de Janeiro (1917); Porto Alegre e Pelotas, no Rio Grande do Sul (1917) e na cidade de Rio Grande, no mesmo estado (1918 e 1919); Salvador (1919); Recife (1919); e Porto Alegre (1919)..$^{63}$ É importante salientar, entretanto, que essas greves não eram, em si, anarquistas ou revolucionárias.

No caso baiano, à intensificação das manifestações grevistas verificada no biênio1919$1920,{ }^{64}$ correspondeu um significativo incremento em termos de sindicalização e politização da classe operária. Os números são interessantes: até junho de 1919, havia 16 sindicatos de resistência organizados em Salvador, sendo que da greve geral até 1921 outras 17 sociedades de resistência foram formadas, além de uma federação operária, que logo reuniria cerca de 25 mil filiados, um partido socialista e dois jornais laborais. ${ }^{65} \mathrm{O}$ fantasma de uma revolução proletária, encarnado na experiência russa de 1917, assombrava, assim, a grande imprensa baiana, que noticiava as ações "maximalistas" pelo globo e pelo Brasil. Manchetes como: "A caudal do maximalismo - O perigo 'bolchevique' toma proporções assustadoras A propaganda rubra das novas teorias libertárias" alimentavam esse temor. ${ }^{66} \mathrm{O}$ significado

60 ADDOR, op. cit.

61 Ibidem, p. 174-175. Diferentemente de Addor, Nébias sustenta o argumento que as greves que estalaram em novembro de 1918 no Rio não possuíam vinculação orgânica com a Insurreição Anarquista. Cf.: NÉBIAS, op. cit.

62 O Imparcial, Salvador, 23 jan. 1919.

63 Para uma análise mais detida sobre essa conjuntura, cf.: FAUSTO, op. cit., p. 157-191 e BANDEIRA, Moniz; MELO, Clóvis; ANDRADE, A. T. O ano vermelho: a revolução russa e seus reflexos no Brasil. Rio de Janeiro: Civilização Brasileira, 1967.

64 FONTES, op. cit., p. 60.

65 CASTELLUCCI, op. cit., 2004, p. 164-165.

66 Maximalistas, cuja proposta consistia em realizar o programa máximo do socialismo, eram assim chamados 
negativo desses movimentos era, via de regra, ressaltado pela imprensa; o medo de uma transformação violenta da ordem social incidia sobre o conjunto das classes dominantes. Como esclarece Alves, "as notícias sobre a revolução" russa, na imprensa baiana, eram marcadas pela noção de que aquele acontecimento encerrava em si uma ameaça aos valores acalentados pelas "sociedades ocidentais e cristãs, como a brasileira". ${ }^{67}$

Após o frustrado levante, Agripino Nazareth ainda permaneceu na capital federal por dois meses, graças à inabilidade da polícia carioca, inclusive escrevendo para o periódico $A B C$, até janeiro de 1919, quando foi pronunciado, ao lado dos outros líderes, como incurso no artigo 107 do Código Penal, "por prática de crime contra a Constituição da República e sua Forma de Governo". Então, utilizando-se de nome falso e fugindo da onda repressiva, dirigiu-se para o interior do estado do Rio e de lá para a capital do Espírito Santo. Dali, partiu para sua terra natal, Salvador, tencionando evadir-se para a Europa, caso fosse necessário. 68

No dia seguinte à conferência ministrada por Nazareth em $1^{\circ}$ de junho, os operários que trabalhavam nas obras de construção do edifício da Biblioteca Pública do Estado, ao voltar do almoço, suspenderam os serviços reivindicando jornada de oito horas e aumento salarial de $20 \%$. Retornamos, aqui, ao ponto inicial de nossa história: o começo das jornadas de junho de 1919. Os acontecimentos se sucederam com crescente intensidade. Concentrando-se inicialmente na praça Rio Branco, os grevistas saíram em passeata pelas ruas centrais, sob "vivas ao operariado baiano" e carregando cartazes improvisados nos quais se liam "8 horas de trabalho são bastante". Os paredistas, que permaneciam em atitude pacífica, logo conseguiram a adesão de operários em construção que trabalhavam em outras obras, como a do Palácio do Governo e do Tesouro do Estado, por exemplo. Caminhando em direção à Ladeira da Barra, pediram apoio aos jornais oposicionistas O Imparcial e Diário da Bahia, no que foram atendidos. Quando retornaram para a sede do SPCDC, localizado na rua Maciel de Baixo, 24, Pelourinho, totalizavam mais de mil manifestantes, contando inclusive com aderentes de outras categorias: trabalhadores em padarias, pintores e funcionários da Companhia Linha Circular. Naquela mesma noite, reunidos na sede do SPCDC e orientados pelo advogado Agripino Nazareth - que, segundo seu próprio depoimento, de meses depois, considerava temerária a parede levada a cabo por um sindicato recém-criado, com poucos sócios e parcos recursos - os operários decidiram generalizar a greve como forma de ampliar suas chances de vitória. Dessa reunião participaram os membros da diretoria do SPCDC, da

os defensores do regime soviético russo no Brasil. Não raro eram também denominados de anarquistas, bolchevistas e/ou comunistas nas notícias veiculadas pela grande imprensa baiana do período. Cf.: ALVES, Cristiano Cruz. Um espectro ronda a Bahia: o anticomunismo da década de 1930. 2008. Dissertação (Mestrado em História) - Faculdade de Filosofia e Ciências Humanas, Universidade Federal da Bahia, Salvador, 2008. p. 22. A citação encontra-se em: Jornal de Notícias, Salvador, 8 abr. 1919. Sobre a circulação do termo maximalismo no Brasil, cf.: BARTZ, Frederico Duarte. O maximalismo como problema: circulação e apropriação da ideia de bolchevismo no movimento operário brasileiro durante os primeiros anos da Revolução Russa. Izquierdas, n. 31, p. 235-248, dez. 2016

67 ALVES, op. cit., p. 21.

68 NAZARETH, Agripino. Ao povo baiano. Jornal de Notícias, Salvador, 15 jun. 1919. 
União Defensora e Beneficente dos Pintores da Bahia e da Sociedade União dos Operários em Padaria, além de lideranças não nomeadas pelos jornais. ${ }^{69}$

Ficou decidido, então, mais uma vez por sugestão de Nazareth, que se formariam três comissões operárias, para se entender com os empreiteiros, com a imprensa e com os poderes competentes. Podemos perceber, assim, que a predominância dos trabalhadores da construção civil nesse momento da parede se evidenciava no próprio caráter das comissões, que se voltavam para os interesses mais específicos dos operários daquele setor. Em seguida, outras três comissões foram formadas, por dez operários cada uma, com o objetivo de conseguir mais adesões entre as diversas categorias de trabalhadores que ainda não haviam se incorporado à paralisação. Nessas últimas comissões a chefia caberia a membros do SPCDC. ${ }^{70}$ Além da generalização da greve ficou estabelecido, também nessa reunião, seu caráter pacífico, desprovida de quaisquer "intuitos revolucionários", ${ }^{71}$ visando estimular a neutralidade do governo do estado para com os paredistas, o que de fato se verificou.

É importante frisar que a paralisação, iniciada pelos operários da construção civil, não parece ter sido incentivada apenas pelas palavras de Nazareth na conferência de propaganda sindical de $1^{\circ}$ de junho, afinal, o advogado confirmou, em matéria na qual rememorava aqueles eventos, a autonomia do movimento, reconhecendo que não houve um planejamento antecedente para preparar a greve geral. Segundo esse relato, a parede "foi a resultante de um concerto entre meia dúzia de trabalhadores nas obras da biblioteca, durante o almoço, e logo após declarada, para a conquista do dia de oito horas". ${ }^{72}$ Até então, Nazareth nem ao menos sabia que uma greve eclodira na cidade:

\begin{abstract}
lembro que descendo casualmente a rua Chile, nessa tarde de 2 de junho, defrontei com a pequena massa grevista. Lobrigando [enxergando] entre ela vários operários que eu havia conhecido na véspera, por ocasião da conferência por mim realizada neste Sindicato, e na qual tratara apenas de incentivar o movimento associativo, não insinuando, nem ao menos veladamente, uma 'greve'. ${ }^{73}$
\end{abstract}

Sem diminuir a importância do papel desempenhado por Nazareth, devemos considerar, como Fontes já admitiu, ${ }^{74}$ a existência de operários mobilizados em sindicatos para a conquista de direitos trabalhistas, que funcionaram como o "combustível" sobre o qual caíra a "faísca" da conferência de Nazareth, fazendo explodir o movimento grevista. Além disso, como já referimos, a influência das lutas operárias de outras regiões do país parece ter sido importante para a eclosão da paralisação, pois a conquista da jornada de oito horas pelos trabalhadores da construção civil do Rio de Janeiro - desde $1^{\circ}$ de maio daquele ano - foi, segundo o próprio Nazareth, o motivo apresentado pelos operários das obras paralisadas no dia 2 de junho para

69 GUIMARÃES, op. cit., p. 87-88.

70 Diário da Bahia, Salvador, 3 jun. 1919; Jornal de Notícias, Salvador, 4 jun. 1919.

71 O Tempo, Salvador, 8 dez. 1919.

72 O Tempo, Salvador, 6 dez. 1919.

73 Ibidem.

74 FONTES, op. cit., p. 173-174. 
cruzarem os braços. ${ }^{75}$ Observamos, assim, mais um componente importante para a eclosão da greve geral de 1919, na Bahia, pois, como Petersen já demonstrou, o movimento operário nacional ultrapassava os limites regionais, propiciando conexões que devem ser alvo de investigação na construção da história do sindicalismo brasileiro. ${ }^{76}$

Nos dias seguintes, sob a orientação da direção do SPCDC e de seu advogado, Nazareth, constitiu-se um Comitê Central de Greve e a parede generalizou-se, ganhando a cidade, virtualmente paralisando-a até a vitória do movimento. Os trabalhadores da construção civil também garantiram o atendimento de suas reivindicações, conquistando aumento salarial e o estabelecimento da jornada de oito horas, mas esta apenas nas obras públicas estaduais. ${ }^{77}$ Não é nosso objetivo realizar aqui uma descrição detalhada desse movimento. Importa reter, nesse momento, a centralidade do papel dos operários sindicalizados da construção civil na eclosão, orientação e vitória da mobilização grevista, que praticamente suspendeu as atividades produtivas de Salvador.

\section{O pós-greve: o SPCDC pela lei versus o SPCDC contra a lei}

Após A GREVE GERAL, trabalhadores e patrões de Salvador voltariam a protagonizar embates, sempre referenciados nas jornadas de junho de 1919, marco inescapável das manifestações operárias da conjuntura em tela. Enquanto os operários as concebiam como um ponto de inflexão nas lutas contra a exploração a qual eram submetidos, os empregadores consideravamna uma fonte de estímulos subversivos. Com o fim da parede, os representantes da oposição, reunidos em torno da figura de Ruy Barbosa e dos grandes industriais e comerciantes, afirmavam pelas páginas da imprensa seu repúdio aos acontecimentos ocorridos em Salvador. A greve, que em seu princípio era vista por eles como um movimento justo e credor das simpatias públicas, passou a ser encarada como uma ação subversiva, anárquica. Num contexto de cisão interoligárquica, o insucesso em utilizar a classe operária contra o seabrismo situacionista deu lugar a críticas ao operariado, acusado, agora, de massa de manobra nas mãos do governo contra a oposição ruísta e seus aliados do comércio e da indústria. Dessa forma, manchetes como "Greve, não: anarquia!"78 e "O Soviete dos Monizes"79 (referência ao governador Antônio Moniz, aliado de J. J. Seabra) estampavam o descontentamento com que os patrões viam as recentes ações operárias e suas virtuais ligações com o governo estadual. $\mathrm{Na}$ interpretação de O Imparcial, periódico alinhado aos grandes industriais e ao ruísmo, o movimento grevista teria sido "estimulado pessoalmente pelo sr. governador do estado

75 CASTELLUCCI, op. cit., 2005, p.148.

76 PETERSEN, Sílvia Regina F. Cruzando fronteiras: as pesquisas regionais e a história operária brasileira. In: Araújo, Angela Maria Carneiro (org.). Trabalho, cultura e cidadania: um balanço da história social brasileira. São Paulo: Ed. Scritta, 1997. p. 85-103.

77 Diário Oficial do Estado da Bahia, Salvador, 10 jun. 1919.

78 Diário de Notícias, Salvador, 10 jun. 1919.

79 Diário da Bahia, Salvador, 11 jun. 1919. 
contra as classes conservadoras". "À sombra de justas aspirações proletárias", argumentava a folha, o governo dera guarida "à anarquia bolcheviquista", transformando Salvador em "um Petrogrado de Lênin ou uma Berlim dos Sapartacistas". 80 O próprio Ruy Barbosa, em conferência realizada no Teatro Politeama, na capital baiana, em 20 de novembro de 1919, emitiu julgamento sobre a conduta do governo do seabrista Antônio Moniz em relação ao problema operário, acusando-o de inspirar, excitar e acobertar "as greves, as ameaças de saque, os esboços de masorca, as encenações de comunismo". ${ }^{81}$

Consoante essa interpretação, o governador do estado seria o mentor da greve geral, secundado em sua "obra satânica" pelo "agitador amestrado" e "testa de ferro", Agripino Nazareth e pelo "pessoal das obras intermináveis do governo", no caso os trabalhadores da construção civil, organizados no SPCDC. De acordo com esse entendimento, as outras categorias profissionais teriam sido "levadas pela boa fé e arrastadas pelos sentimentos os mais nobres de uma justa reivindicação dos seus direitos", sem que tivessem "em vista perturbar a ordem e sobressaltar a sociedade baiana". As acusações de maximalismo e anarquia eram endereçadas, dessa maneira, ao governo do estado - que teria manipulado o advogado Agripino Nazareth e os operários das obras do governo - sem se estender, contudo, ao conjunto do operariado. ${ }^{82}$

É interessante ressaltar o papel de núcleo articulador do SPCDC durante a greve geral, contando com o auxílio valioso de lideranças de outras categorias e a militância de Agripino Nazareth, reunidos no Comitê Central de Greve. Pois, como o próprio Nazareth dissera em conferência na sede do SPCDC, meses depois daquela jornada, "a parede geral foi genuinamente obreira, isenta de influências palacianas, desde seu início até que terminou". ${ }^{83}$ É bem verdade que logo em seguida à greve os patrões tentaram reverter suas conquistas, descumprindo os acordos celebrados, o que ensejaria novas paralisações - não tão vigorosoas - nos meses seguintes. Ao mesmo tempo, o incremento na organização sindical foi notável, tendo atingido, nos dias imediatamente posteriores ao fim da greve na capital, a região do Recôncavo. Houve paralisações nas cidades de Nazaré, São Félix, Muritiba e Cachoeira. ${ }^{84}$

O processo de progressiva politização do movimento operário consubstanciou-se na organização de sindicatos operários de resistência - em Salvador e no Recôncavo - junto a categorias até então sem agremiação em bases sindicais, como os têxteis, os marceneiros, os alfaiates, os fumageiros, entre outros. Esse processo mobilizador e organizativo continuará a prosseguir sob a influência predominante do SPCDC, que, fortalecido pelos laços de solidariedade firmados com outras categorias laborais durante a greve geral e pelo aumento quantitativo de seus associados, será o principal responsável pela convocação, organização

80 O Imparcial, Salvador, 11 jun. 1919.

81 BARBOSA, Ruy. Obras Completas de Ruy Barbosa, v. XLVI, t. III, 1919, p. 27-28 (Disponível em: http://www. docvirt.no-ip.com/ObrasRui/STF_Biblioteca.htm. Acesso em: 15 maio 2012).

82 Diário da Bahia, Salvador, 11, 12 e 13 jun. 1919.

83 O Tempo, Salvador, 6 dez. 1919.

84 CASTELLUCCI, op. cit., 2004, p. 230-232. 
e consecução do denominado Primeiro Congresso dos Trabalhadores Baianos, em julho de 1919,85 importante passo no sentido de constituir um movimento operário autônomo, articulado e coordenado em relação aos métodos e fins da ação sindical no estado. Desse conclave surgirão as orientações gerais que guiarão o SPCDC e as associações operárias sob sua esfera de influência até o ano seguinte, culminando com a fundação da Federação dos Trabalhadores Baianos (FTB), em fevereiro de 1920. Entretanto, ao incremento qualitativo e quantitativo verificado no movimento operário do pós-greve geral, opôs-se uma reação patronal cada vez mais acentuada.

Dois marcos são representativos dos avanços políticos e organizacionais, das resistências sofridas e dos dilemas ideológicos que se apresentaram aos militantes do SPCDC na conjuntura que se seguiu às jornadas de junho de 1919: o Primeiro Congresso dos Trabalhadores Baianos e o confronto do largo de São Bento, em maio de 1920.

No fim do mês de junho, a partir do dia 27 , circularam pela imprensa notícias que afirmavam ser iminente a eclosão de outra parede em Salvador, o que causou preocupação entre os industriais e comerciantes, assim como nas oposições ruístas. ${ }^{86}$ Pelo Diário Oficial, no entanto, o governo informou que Álvaro Cova, secretário de Segurança, assegurava não haver "fundamento o boato" e que "a população da capital" podia serenar-se, pois "a ordem", foi prometido, "não se alterará". ${ }^{87}$ Os rumores sobre o pretenso movimento, que deveria estourar no dia $1^{\circ}$ de julho, estariam calcados em boletim emitido pelo SPCDC, cujo conteúdo consistia em uma convocação aos seus associados para reunião na qual seriam discutidos assuntos "urgentes", atinentes aos interesses da categoria. Visando esclarecer essa situação, uma comissão de sócios do sindicato visitara na noite de 27 de junho a redação do periódico O Democrata, assegurando que não havia intenção alguma de decretar nova greve. ${ }^{88}$

Todavia, de nada adiantou o desmentido, pois, para a Associação Comercial, tramava-se, sim, "outro movimento subversivo". O temor da entidade patronal, que se arrogava representante de "todas as forças mantenedoras do trabalhador, da ordem, da paz e da conservação da sociedade", era justamente em relação aos convites "de sindicatos e associações que haviam se notabilizado" na recente greve geral e que "já estavam sendo distribuídos pela capital, e afixados às esquinas das ruas". O presidente da ACB Rodolfo Martins oficiou, então, o governador Moniz, externando seus receios em relação àquela reunião operária, que congregaria, no seu entendimento, "elementos apontados pela cidade inteira como subversivos da ordem pública (...), na sede do Sindicato, ao Maciel de Baixo, $n^{\circ} 24 " .{ }^{89}$ O governador replicou que estava ciente de tais anúncios, mas que não havia com o que se preocupar, pois a temida greve não passava de rumores, achando-se, de qualquer

85 Na realidade houve um congresso operário anterior a este, patrocinado pela Federação Socialista Baiana, em 1907. Cf.: SANTOS, op. cit., p. 369.

86 Diário de Notícias, Salvador, 27 jun. 1919; Jornal de Notícias, 27 jun. 1919.

87 Diário Oficial do Estado da Bahia, Salvador, 27 jun. 1919.

88 O Democrata, Salvador, 28 jun. 1919.

89 BOLETIM da Associação Comercial da Bahia de julho de 1919. 
forma, o governo "aparelhado para manter a ordem, garantindo em sua plenitude, todos os direitos". ${ }^{90} \mathrm{O}$ simples gesto de se convocar o operariado para reuniões, vindo do grupo que deflagrara e orientara a greve de junho, excitava o alto comércio, que enxergava em tal iniciativa "intuitos subversivos".

Já no dia 28 de junho, a ACB declarava "à sociedade baiana em geral, e, em especial, ao comércio", que não havia mais "nenhuma iminência" de alteração da ordem. ${ }^{91}$ Na realidade, a série de reuniões programada pelo SPCDC relacionava-se à articulação necessária para a organização do Primeiro Congresso dos Trabalhadores Baianos. Consoante esse objetivo, um convite para o congresso, reproduzido em boletim da $A C B$, demonstra a intenção de agregar o maior número possível de categorias laborais, inclusive aquelas em que as mulheres eram majoritárias, sem olvido até mesmo das empregadas domésticas. Assim sendo, convocavam-se as trabalhadoras dos "ateliês, camisarias, sapatarias, fábricas, laboratórios, charutarias e casas particulares", além das "lavadeiras, engomadeiras, cozinheiras e mais trabalhadores em serviços domésticos a comparecerem na sede do Sindicato". ${ }^{22}$

O congresso foi marcado para ocorrer entre os dias 14 e 20 de julho de 1919 e era extensivo para todo o estado. ${ }^{93}$ No dia 4 de julho, o Jornal de Notícias publicava uma circular da comissão promotora - não por acaso, justamente os componentes da diretoria do SPCDC. A meta era que se estabelecessem princípios comuns que fornecessem coesão e força fundamentais para manter e alargar "as melhorias morais e materiais alcançadas (...) em virtude da recente greve geral" ${ }^{94}$ Destarte, o objetivo do SPCDC era manter o moral dos trabalhadores elevado e, assim, aproveitar a experiência da greve de forma a não perdê-la, visando acumular algum ganho político, material e organizativo.

A instalação do encontro teve lugar no tradicional Teatro São João, às 15 horas do dia 14 de julho, um domingo, diante da presença de representantes do governador do estado, do comandante da $5^{\text {a }}$ Região Militar, do secretário de polícia, da imprensa, assim como de várias delegações de trabalhadores. Ao notar esse fato, Castellucci refletiu que essa presença de "autoridades civis, militares e do Estado" significava que a classe trabalhadora não ficaria imune às "influências políticas ou mesmo ideológicas externas". ${ }^{55}$ Talvez a intenção fosse manter uma espécie de neutralidade simpática por parte do governo estadual em relação às organizações sindicais reunidas em torno do SPCDC e de Agripino Nazareth. Seja como for, a sessão inaugural do certame daria o tom de respeito às instituições e às leis como condição para que os trabalhadores de Salvador alcançassem a justa recompensa por seu labor. O orador oficial, José dos Santos Gomes, operário pedreiro, iniciou sua fala elucidando

90 Jornal de Notícias, Salvador, 1 jul. 1919.

91 Diário de Notícias, Salvador, 28 jun. 1919.

92 BOLETIM da Associação Comercial da Bahia, ano XI, n. VII, julho de 1919, p. 7.

93 A Tarde, Salvador, 30 jun. 1919. Não por acaso, a data de instalação do congresso, 14 de julho, coincidia com a da Queda da Bastilha, marco cronológico da Revolução Francesa.

94 Jornal de Notícias, Salvador, 4 jul. 1919.

95 CASTELLUCCI, op. cit., 2004, p. 246. Este também é o ponto de vista dos irmãos Rubim, op. cit., p. 29. 
o porquê da escolha do dia 14 de julho como data de abertura do congresso. Elogiando a Revolução Francesa, o que, aliás, já havia acontecido na circular de convocação, explicava que a data era vista como o "dia maior da Humanidade, consagrado à conquista dos direitos do homem", símbolo da "vitória da liberdade", quando "cessou a escravidão do fraco", que "vestiu a toga de cidadão" e pôde, enfim, desbaratar "os abusos do governo, exprimir suas opiniões e escolher seus representantes e dirigentes". Dessa forma, continuava, "estava iniciada a igualdade perante a lei". Ressaltando a centralidade da busca pelo reconhecimento da cidadania do proletariado, o orador destacava a importância de estabelecerem "princípios sobre os quais" fosse possível "reclamar os direitos que nos são conferidos pela nossa Carta Magna, código civil e demais leis que oferecem garantias às classes trabalhadoras". Isto significa que recorrer às esferas institucionais e legais era, então, interpretado como uma estratégia possível - e mesmo conveniente - no sentido de garantir o usufruto de direitos sociais e políticos inalienáveis, por parte dos trabalhadores. Sendo assim, a importância da educação, da instrução profissional e do trabalho - "que honra e dignifica" - era assinalada com o pedido "ao poder público" para que este organizasse uma "assistência às escolas primárias" e "junto às fábricas e escolas profissionais, procurando reprimir a vadiagem, a fim de que não desapareça o artista nacional". ${ }^{96}$

A consciência de que os artistas e operários, e "não somente os intelectuais", também concorriam "para a civilização e progresso social", significava, como demonstrou Gomes, que o trabalho era concebido como um "valor positivo", do qual derivava "a dignidade da figura do trabalhador e o seu papel central no mundo econômico e social". Ou seja, existia uma percepção de que a classe operária era um "ator coletivo legítimo", sendo portadora de uma "identidade social positiva", portanto de cidadania. ${ }^{97}$ À observação dos direitos dos trabalhadores deveria corresponder o respeito à ordenação jurídica e institucional vigente. Assim, a oração de José dos Santos Gomes afirmava a necessidade de se "conhecer todos os nossos direitos e deveres, uma vez que uns e outros se confundem, evitando desse modo infringirmos as leis, a que prestamos obediência, sentindo-nos fortes e garantidos diante dos poderes do Estado". A greve, nessa interpretação, seria um direito dos operários; porém, prosseguia, "não queremos a greve perturbadora da ordem pública nem que traga a morte da população pela fome, por isso somos daqueles que julgam necessária a ordem, por que dela provirá a harmonia". Não sabemos se o teor desse discurso foi planejado para ser ouvido por aquelas autoridades civis, militares e do Estado presentes na assembleia proletária, e assim desarmá-los em suas reticências ou hostilidade em relação aos integrantes do congresso, mas a proximidade com o discurso patronal é nítida, especialmente no que tange "ao acordo e harmonia do capital e do trabalho", ponto de vista defendido pelo conjunto do patronato. ${ }^{98}$

96 Jornal de Notícias, Salvador, 15 jul. 1919.

97 GOMES, Angela de Castro. A invenção do trabalhismo. Rio de Janeiro: Editora FGV, 2005. p. 17-18 e p. 25.

98 Cf.: Diário da Bahia, Salvador, 5 jun. 1919. 
Antes de julgarmos tal proximidade entre os discursos operário e patronal como indicativo de um desvio do movimento operário, é interessante salientar, como argumenta Fortes, que foi num processo de acúmulo de experiências que os trabalhadores conseguiram "lidar com a lei não apenas enquanto ordem pública inibidora da sua capacidade de manifestação (...), mas também como reconhecimento", ainda que pouco efetivo inicialmente "de sua titularidade a direitos sociais". É no bojo desse processo, portanto, que o operariado se conforma como sujeito de um direito coletivo emergente. ${ }^{99}$ Assim sendo, podemos compreender melhor quando, em seu discurso, o orador oficial do congresso enunciou que "desde que patrões e operários colaborem para um mesmo fim, teremos a riqueza e engrandecimento do país e então todos nós gozaremos destes benefícios". ${ }^{100}$

Encerrando a sessão, diante de um teatro cheio, Agripino Nazareth convidou a audiência "a comemorar o grande dia de 14 de julho, o primeiro marco que assinalou a vitória do socialismo". ${ }^{101}$ Ao conclamar os presentes a acompanhá-lo nesta homenagem, Nazareth nos deixa ver que, mesmo dois anos após a Revolução Russa, a Revolução Francesa ainda era um paradigma válido de caminho para o socialismo para uma parte expressiva do movimento operário brasileiro. ${ }^{102}$

\section{Figura 3 - Teatro São João, local que abrigou o Primeiro Congresso dos}

Trabalhadores Baianos, em julho de 1919 (postal datado de 1911).

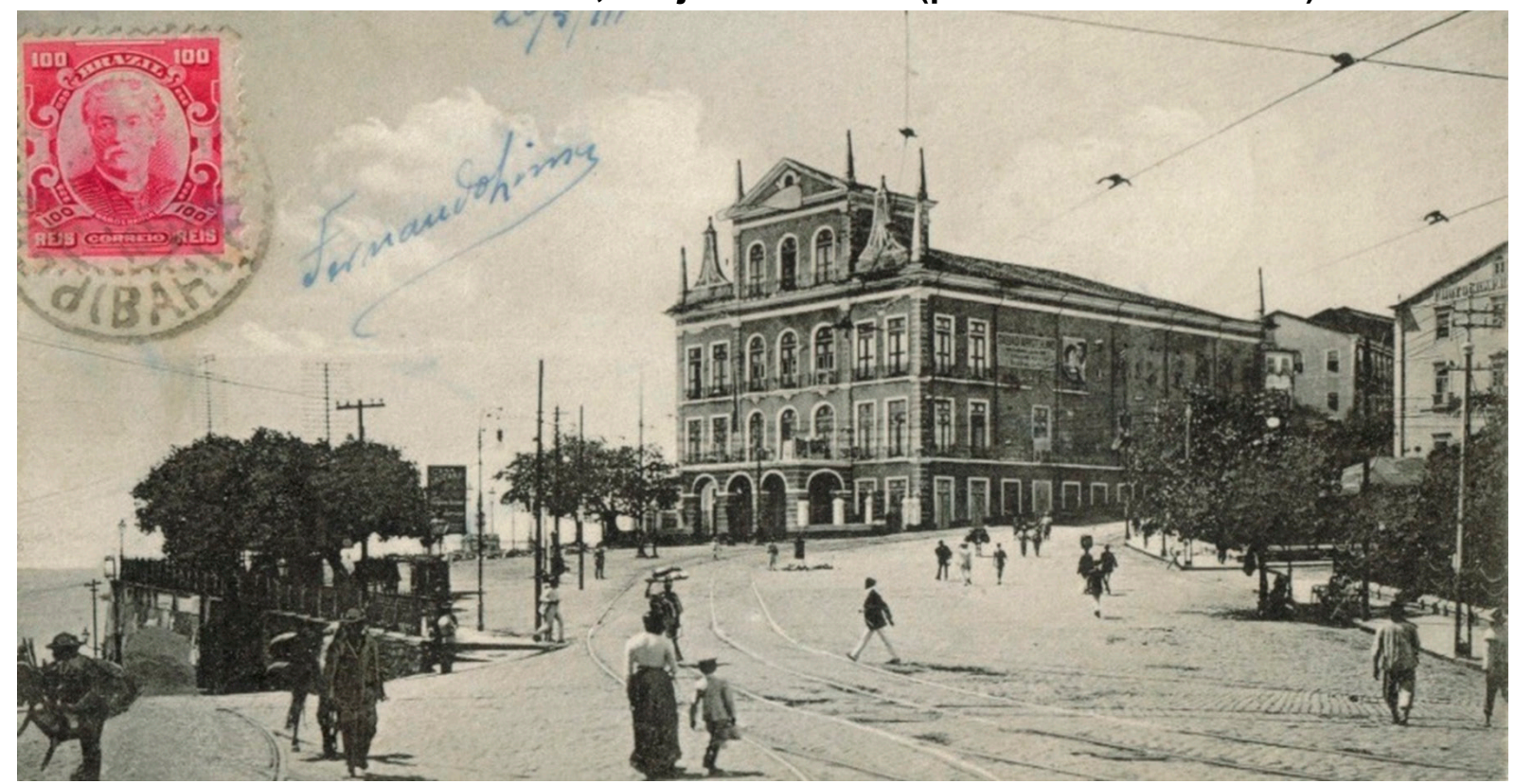

Fonte: Disponível em http://4.bp.blogspot.com/-eSKfyOf-n4A/ToX5iVCcA-I/AAAAAAAABFY/Cxc9b0RM4U/s1600/Bahia+-+T.+S.+Joao.jpg. Acesso em: 25 jun. 2020.

99 FORTES, Alexandre. Os direitos, a lei e a ordem - greves e mobilizações gerais na Porto Alegre da I República. In: LARA, Silvia Hunold; MENDONÇA, Joseli Maria Nunes (org.). Direitos e justiças no Brasil: ensaios de história social. Campinas: Editora da Unicamp, 2006. p. 374.

100 Jornal de Notícias, Salvador, 15 jul. 1919.

101 O Democrata, Salvador, 16 jul. 1919.

102 Cf.: BATALHA, Claudio H, M. Nós, filhos da Revolução Francesa: a imagem da revolução no movimento operário brasileiro no início do século XX. Revista Brasileira de História, São Paulo, v. 10, n. 20, p. 233-249, mar.-ago. 1991. 
Esse entendimento de socialismo, que lutava pela aquisição da cidadania operária pela lei e que se pretendia respeitador da ordem, seria enfatizado no encerramento do encontro, quando por aclamação a assembleia aderiu ao mesmo socialismo coletivista professado por Nazareth. ${ }^{103}$ Essa orientação ideológica permitiu que o congresso operário fizesse muitas solicitações aos poderes públicos, como também nutrisse a expectativa de assegurar direitos na esfera legal. Longe de ser visto como um inimigo, o Estado era concebido, naquele momento, como um interlocutor válido no encaminhamento das demandas operárias, ponto de vista que deve ter se fortalecido após a atuação do governador Antônio Moniz por ocasião da greve geral, quando intermediou as negociações entre patrões e empregados, e com a criação de leis estaduais que estabeleciam a jornada de oito horas de trabalho em suas oficinas, indústrias e obras públicas, além da decretação do Primeiro de Maio como feriado estadual. ${ }^{104}$ Tendo isso em mente, Castellucci construiu a concepção de que "convocado e fortemente influenciado pelo Sindicato de Pedreiros, Carpinteiros e Demais Classes e seu advogado Agripino Nazareth", o congresso operário "foi dominado pelas correntes sindicais reformistas", distantes, assim, de um projeto revolucionário. ${ }^{105}$ É importante sublinhar que tal influência figuraria, ainda, nos estatutos do SPCDC, finalizados por Nazareth, ${ }^{106}$ assim como nos regulamentos da FTB, que também contaram com sua contribuição. ${ }^{107}$

Diante do exposto, devemos agora avançar até maio de 1920, a fim de observarmos outra manifestação operária com ampla participação de militantes do SPCDC. Preocupada com a questão da carestia de vida, a Federação dos Trabalhadores Baianos (FTB) agendou uma manifestação para o dia 25 de maio de 1920, em frente à Biblioteca Pública do Estado, na praça Rio Branco, coração administrativo de Salvador - e da Bahia. ${ }^{108} \mathrm{O}$ ato teve início às cinco horas da tarde, com oradores discursando nas escadarias daquele edifício a respeito da alta de preços dos gêneros de primeira necessidade. As versões dos periódicos da grande imprensa sobre os acontecimentos que então tiveram lugar divergem em alguns pontos periféricos, mas no geral coadunam-se.

103 GUIMARÃES, op. cit., p. 117.

104 Ibidem.

105 CASTELLUCCI, op. cit., 2004, p. 244.

106 A Tarde, Salvador, 9 ago. 1919.

107 A Voz do Trabalhador, Salvador, 10 mar. 1920.

108 Situavam-se neste local: o Palácio Rio Branco, sede do governo estadual, e a Intendência de Salvador, sede da administração municipal. 
Figura 4 - Biblioteca Pública do Estado da Bahia - Anos 1920.

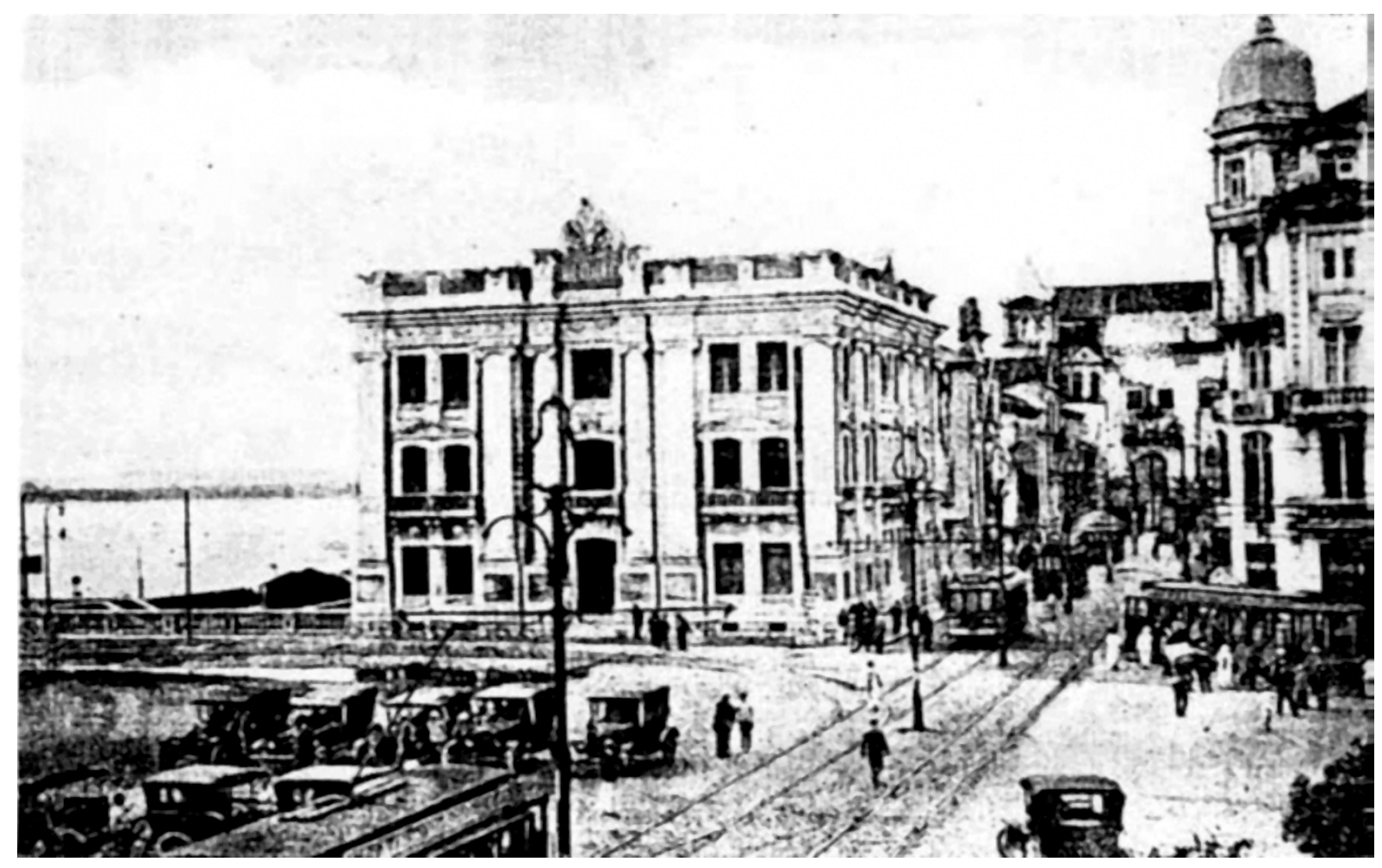

Fonte: Vistas da Cidade do Salvador. Rio de Janeiro: Pimenta de Mello \& C.,[s.d.] apud PINHEIRO, Eloísa Petti. Europa, França e Bahia: difusão e adaptação de modelos urbanos (Paris, Rio e Salvador). Salvador: EDUFBA, 2011. p. 278.

Por volta das sete horas da noite, um dos manifestantes conclamou o público presente ao comício para rumar até a residência do governador J. J. Seabra (que havia tomado posse poucos meses antes), a fim de the cobrar providências. Com tal fito, seguiram em passeata pela rua Chile, voltando a concentrarem-se na altura da praça Castro Alves, onde, segundo O Imparcial, "discursos francamente anarquistas" foram ouvidos. ${ }^{109}$ Ciente da intenção da marcha, o primeiro delegado auxiliar Pedro Gordilho dirigiu-se à residência do secretário de Segurança - Antônio Seabra, filho de J. J. Seabra - enquanto um grupo de cinco praças do Corpo de Cavalaria era despachado para estacionar no alto da Ladeira de São Bento, com ordens de impedir o avanço do préstito. Naquela altura, o protesto já formava uma "grande massa popular". ${ }^{110}$ Quando Pedro Gordilho retornou do encontro com o secretário Seabra, deparou-se com uma pequena multidão forçando a passagem diante dos cavalarianos da polícia, no largo de São Bento. Procurando demover os reclamantes de seus intuitos de avançarem pela avenida Sete de Setembro até a residência do governador, Gordilho instou que nomeassem uma "comissão para se entender com o governo". ${ }^{111}$

109 O Imparcial, Salvador, 26 maio 1920.

110 Diário de Notícias, Salvador, 26 maio 1920.

111 A Manhã, Salvador, 26 maio 1920. 
Figura 5 - Rua Chile, contígua à praça Rio Branco.

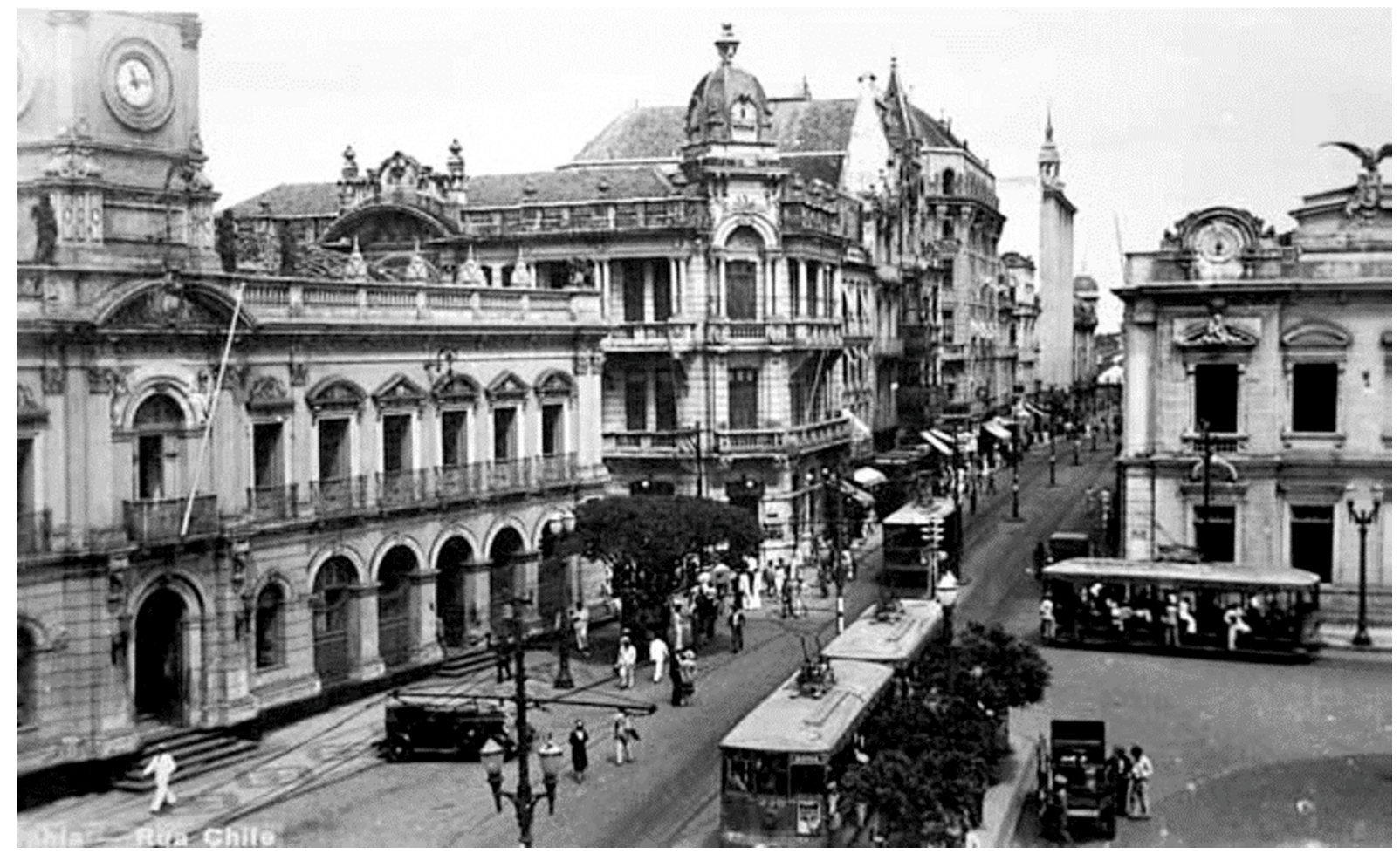

Fonte: IFB - Instituto Feminino da Bahia apud PINHEIRO, 2007, op. cit., p. 228.

Figura 6 - Ladeira de São Bento vista da praça Castro Alves. Na parte superior, encontra-se o largo e o Mosteiro de São Bento (anos 1920 - postal colorizado).

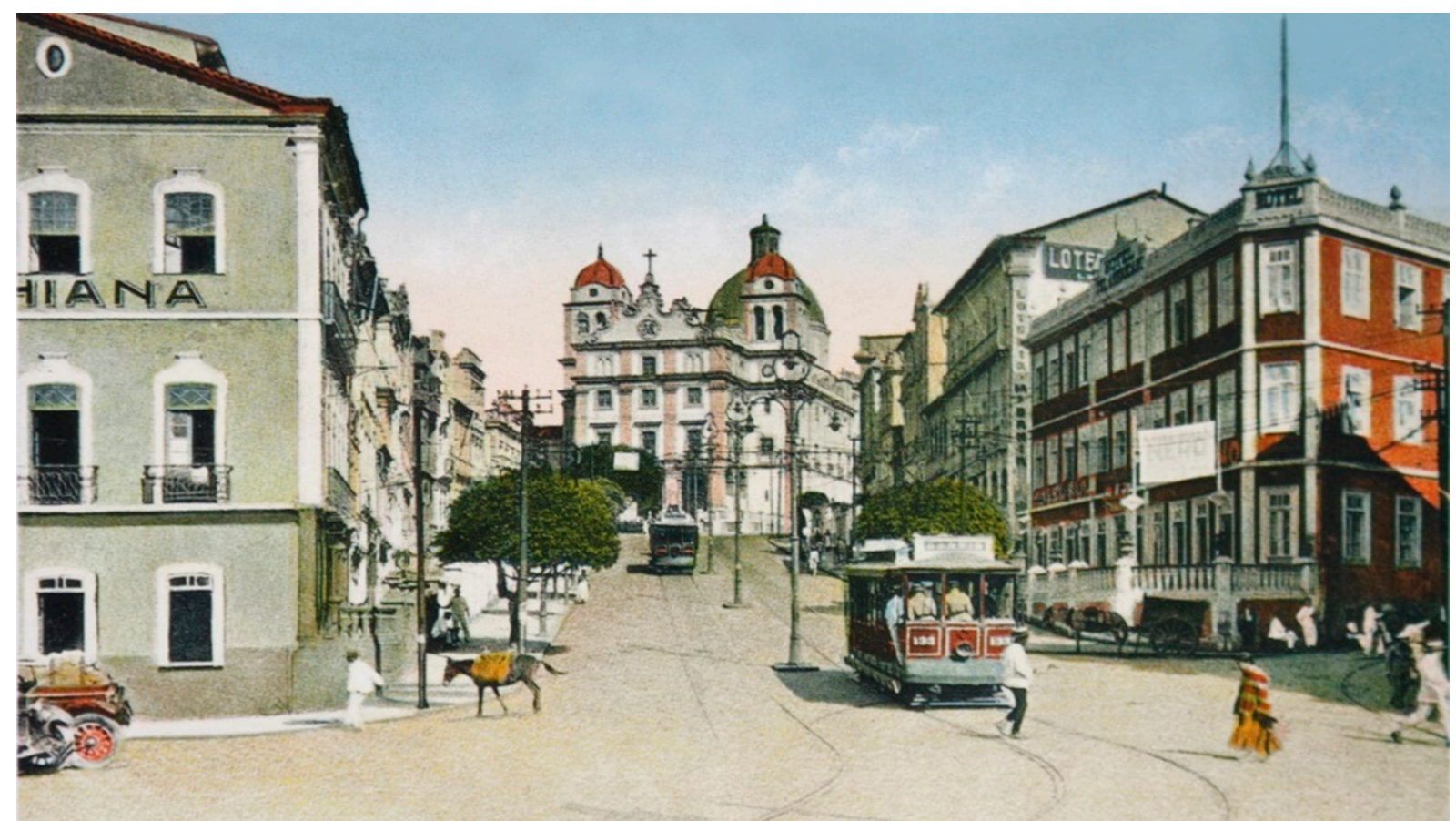

Fonte: http://www.salvador-antiga.com/imagens/sao-bento-salvador.jpg. Acesso em: 25 jun. 2020.

O delegado argumentava que aquela não era a maneira mais adequada para reivindicar uma ação governamental, afirmando haver um familiar doente na casa do governador. Em réplica, 
os protestantes começaram a gritar “"morras' ao governo e blaterar contra o Estado". ${ }^{112}$ Também acusaram Seabra de estar "dominado pela burguesia", ameaçando "obrigá-lo a fazer baixar" os preços dos gêneros de primeira necessidade. ${ }^{113}$ Nesse momento, um tiro teria partido dos manifestantes visando o delegado. Escapando ileso, Gordilho ordenou, então, aos policiais que atirassem para o ar, o que resultou na dispersão da manifestação. Efetuou-se, em seguida, "a prisão do chefe do movimento subversivo, como único meio de se restabelecer a ordem pública". ${ }^{114} \mathrm{~A}$ aprovação da grande imprensa à conduta das forças de segurança foi unânime. A FTB, por seu turno, não ficou inerte frente à repressão policial. Contestando a versão oficial dos fatos, telegrafou à folha carioca Voz do Povo, órgão da Federação dos Trabalhadores do Rio de Janeiro, denunciando que o comício operário havia sido "dissolvido à bala". A Comissão Executiva do Terceiro Congresso (encarregada pelo $3^{\circ}$ Congresso Operário Brasileiro - ocorrido em abril de 1920, na capital federal - de implementar a articulação da Confederação Operária Brasileira em nível nacional), por sua vez, telegrafou ao governador Seabra, protestando pela violência empregada contra os trabalhadores baianos. ${ }^{115}$

Mas, se naquele momento era o socialismo a ideologia desposada pela federação, por vários sindicatos soteropolitanos, ${ }^{116}$ assim como por seu ativista mais destacado, como compreender, então, que manifestantes envolvidos naquele comício de 25 de maio de 1920 proferissem "discursos francamente anarquistas"?

Uma possibilidade para entendermos o que estava sucedendo encontra-se na mesma matéria em que $O$ Imparcial tratou dos eventos referentes ao rumoroso ato promovido pela FTB. Segundo este relato, os incidentes registrados naquele episódio estariam intimamente vinculados à presença no seio das classes trabalhadoras de Salvador de "alguns anarquistas recentemente chegados do Rio". Foram esses "anarquistas", afirmava o jornal, que "ao final do meeting usaram da palavra, pregando violentamente contra o clero, a burguesia, a imprensa e o governo". Também teria partido deles a incitação para que os manifestantes seguissem até a residência de Seabra e impusessem ao governador a baixa dos preços dos alimentos. ${ }^{117}$ Ou seja, a responsabilidade pelo que o periódico chamou de "movimento subversivo" caberia àqueles indivíduos anarquistas estranhos ao estado, oriundos do Rio de Janeiro.

Reativava-se, destarte, um artifício discursivo que representava o operariado baiano como dócil, produtivo, ordeiro e obediente e, em contraste, oferecia uma visão do trabalhador

112 O Imparcial, Salvador, 26 maio 1920.

113 Diário de Notícias, Salvador, 26 maio 1920.

114 Ibidem.

115 Voz do Povo, Rio de Janeiro, 31 maio e 1 jun. 1920.

116 De fato, diversas associações operárias baianas do período, e de perfis distintos, desposavam ideias socialistas, tais como o Grêmio dos Maquinistas da Marinha Civil, que em seu $74^{\circ}$ aniversário, em junho de 1919, afirmava: "o socialismo é o fim da tutela e o começo da vida, o socialismo faz agir e pensar". Cf.: A Tarde, 29 jun. 1919. Outro exemplo é o da Sociedade Beneficente e Defensora dos Eletricistas, que afirmava em seus estatutos guiar-se por "bases socialistas". Cf.: ESTATUTOS da Sociedade Beneficente e Defensora dos Eletricistas. Diário Oficial do Estado da Bahia, Salvador, 14 de fevereiro de 1920.

117 O Imparcial, Salvador, 26 maio 1920. 
exógeno - no caso, proveniente da capital federal - como portador dos perniciosos vetores de subversão e insubmissão. Tal dispositivo encontrava paralelo no entendimento, então em voga em outras regiões do país, que elementos estrangeiros compunham a parcela vanguardeira dos operários envolvidos em paredes. Na mensagem do presidente da República Epitácio Pessoa ao Congresso Nacional em alusão à greve da Leopoldina Railway Company, que em março daquele ano havia sacudido a capital do país, o governante ecoava argumento similar: os grevistas baderneiros eram estrangeiros dissolutos. ${ }^{118}$

De fato, os relatos da grande imprensa sobre o conflito ocorrido após o comício da FTB, no qual se notablizaram aqueles "anarquistas recentemente chegados do Rio", indicavam a percepção de que se operara uma sensível transformação no modus operandi de alguns grêmios laborais de Salvador. Afinal, durante as greves de 1919 e 1920, os operários não se dispuseram a confrontar o poder político do estado. Todas as vezes em que o chefe do Executivo foi procurado naquelas ocasiões, a intenção era buscar seu auxílio ou arbítrio nas questões entre patrões e empregados. Agora, contudo, era diferente: os operários tencionavam, quem sabe, obrigar o governador a Ihes fazer a vontade. Para tanto, lançaram mão de um repertório discursivo que atacava os poderes constituídos, instilando o temor do fantasma do anarquismo nas classes dominantes baianas.

As suspeitas das autoridades policiais pareciam proceder, pois tal emergência radical, ao nosso ver, está diretamente relacionada à questão da circulação geográfica de militantes anarquistas que se evadiram do Rio de Janeiro e se fixaram em Salvador, intentando escapar do peso ascendente da repressão em terras cariocas, após os acontecimentos de novembro de 1918. Dentre eles, encontrava-se Eustachio Pereira Marinho, baiano radicado no Rio, peça-chave no processo de radicalização do SPCDC e no estabelecimento do anarquismo e do método sindicalista revolucionário em Salvador entre 1920 e 1922. Foi provavelmente em função da escalada repressiva na capital federal que Marinho empreendeu o mesmo deslocamento que Nazareth havia realizado meses antes. As fontes pesquisadas assinalam sua presença em território soteropolitano a partir de abril de 1920, quando assinou um artigo no Germinal, ${ }^{119}$ defendendo a necessidade de se empreender uma revolução social para emancipar os trabalhadores. Na sequência, foi um dos muitos oradores na celebração e passeata do Primeiro de Maio daquele ano. ${ }^{120}$ Além disso, e mais uma vez à semelhança de Nazareth, ingressou na associação dos trabalhadores da construção civil. A partir de então, seu itinerário militante vinculou-se aos caminhos percorridos pelo SPCDC, pois tudo indica ter sido ele o principal mentor da radicalização que o sindicato efetuou a partir de setembro de $1920 .{ }^{121}$ Tal compreensão

118 Revista Bahia llustrada, Rio de Janeiro, maio 1920.

119 Germinal, Salvador, 1 maio 1920.

120 Germinal, Salvador, 1 maio 1920. Ao anunciar a programação das celebrações operárias referentes ao Primeiro de Maio, o jornal A Tarde de 29 de abril de 1920 informava que Eustachio Marinho discursaria duas vezes ao longo do percurso da passeata.

121 GUIMARÃES, op. cit., p. 187-199. 
ganha força quando verificamos que Marinho ocupou o posto de secretário-geral daquela associação, pelo menos entre janeiro de 1921 e dezembro de $1922 .{ }^{122}$

Ao contrário de Agripino Nazareth, que se declarava socialista coletivista, Eustachio Marinho reconhecia-se como anarquista. Essas duas posições orientaram progressivamente divergentes formas de encaminhar as demandas operárias presentes no SPCDC. O resultado dessa cisão foi a divisão do sindicato entre os que consideravam que a luta sindical deveria ser complementada pela luta parlamentar, através da criação de um partido socialista, e aqueles que condenavam tal opção, insistindo que os trabalhadores não se imiscuíssem nas disputas eleitorais nem recorressem aos canais institucionais para resolver suas reivindicações, mas que apelassem para o exercício da pressão direta sobre seus empregadores. Nesse processo, o SPCDC perderia importantes quadros, ativos desde a sua fundação, e se desligaria da Federação dos Trabalhadores Baianos - que permaneceu sob a orientação de Nazareth "por questões de princípio e orientação", condicionando sua possível reintegração "até que a mesma volte a ser unicamente sindicalista". ${ }^{123}$

A partir de então, a adoção do método sindicalista revolucionário foi explicitada pelo sindicato da construção civil, através da publicação de um novo jornal: $A$ Voz do Trabalhador ${ }^{124}$ (outubro de 1920 - dezembro de 1922) - no qual Marinho escreveu com regularidade. Em suas páginas encontra-se o temário característico dessa corrente: centralidade da greve como meio para garantir e alargar direitos; apelo à instrução proletária; pregação da revolução social como forma de se edificar a sociedade futura e a emancipação humana, inclusive defendendo a necessidade da violência revolucionária; propaganda da ação direta; apelo à formação de sindicatos de resistência, em oposição às beneficentes e cooperativas; recusa da luta político-parlamentar; antiestatismo; antimilitarismo; anticlericalismo; combate ao alcoolismo, ao futebol, ao carnaval; internacionalismo proletário; amor livre; e greve geral insurrecional. ${ }^{125}$ Outra característica dessa tendência é conciliar a luta para obter vantagens imediatas com a perspectiva de destruição do sistema capitalista, a fim de estabelecer um novo sistema gerido diretamente pelos produtores, em torno de seus sindicatos, livremente associados. $O$ fator máximo de união entre os membros do sindicato deveria ser o econômico. Tudo aquilo que pudesse cindir o operariado - divisões de cor, crença, credo político, nacionalidade - deveria ficar de fora da organização sindical.

\section{Consideraçãoes finais}

Podemos observar, dessa maneira, o distanciamento entre a posição de Nazareth e a de Marinho. Parece certo que naquele momento havia um processo de diferenciação ideológica

122 A Voz do Trabalhador, Salvador, 22 jan. 1921.

123 GUIMARÃES, op. cit., p. 204.

124 Sintomaticamente homônimo ao da Confederação Operária Brasileira, que propugnava o mesmo sindicalismo revolucionário enquanto estratégia de luta e organização dos trabalhadores.

125 Cf.: A Voz do Trabalhador, Salvador, out. de 1920-dez. de 1922. 
correndo subterraneamente no seio da principal animadora da FTB: o SPCDC. Esse processo desaguaria na cisão do sindicato entre agosto e setembro de 1920, quando importantes quadros abandonariam o sindicato, acompanhando o advogado Agripino Nazareth, no momento em que este optou por complementar a luta sindical com a luta política-parlamentar e fundou o Partido Socialista Baiano, em agosto de 1920. ${ }^{126}$

Por seu turno, A Voz do Trabalhador pregava as virtudes do sindicalismo, cuja causa deveria ser defendida até o sacrifício pelos operários, afinal, segundo esse ponto de vista, apenas o sindicalismo poderia preparar e curar "esta Humanidade velha e doentia, para produzir a Humanidade nova e sã". ${ }^{127}$ A legitimidade da luta sindical era evidenciada pela concepção que a ordem social vigente era intrinsecamente injusta, portanto o respeito às suas instituições, organizações e leis deveria ser substituído pela "união de todos os trabalhadores", "a lei suprema, que anula e rasga todas as leis que protegem o Capitalismo e o Poder". ${ }^{128}$ Depois do vendaval ${ }^{129}$ das jornadas de junho de 1919 , os operários da construção civil de Salvador conseguiram imprimir uma marca combativa no interior do movimento operário baiano. Conhecer suas lutas, vitórias e derrotas, suas escolhas, podem contribuir para um entendimento mais complexo a respeito dos mundos do trabalho no Brasil. Através da investigação e análise da experiência e ação dos militantes do SPCDC durante a greve geral de 1919 e nos anos seguintes, tivemos como objetivo, portanto, possibilitar uma compreensão ainda mais nítida e detalhada sobre as lutas e as formas de organização dos trabalhadores daquele momento, assim como entender com mais profundidade as origens e o desenvolvimento de certas forças do movimento operário, como o socialismo de uns e o sindicalismo revolucionário de inspiração anarquista de outros, na Salvador da I República.

Recebido em: 02/07/2020

Aprovado em: 15/08/2020

126 A Tarde, Salvador, 24 ago. 1920.

127 A Voz do Trabalhador, Salvador, 2 out. 1920.

128 A Voz do Trabalhador, Salvador, 9 out. 1920.

129 Expressão cunhada por Castellucci para descrever o contexto que se configurou após as jornadas de junho de 1919. Cf.: CASTELLUCCI, op. cit., 2004, p. 223-267. 